Prepared in cooperation with Gem County and the Idaho Department of Environmental Quality

\title{
Ambient Water Quality in Aquifers Used for Drinking- Water Supplies, Gem County, Southwestern Idaho, 2015
}
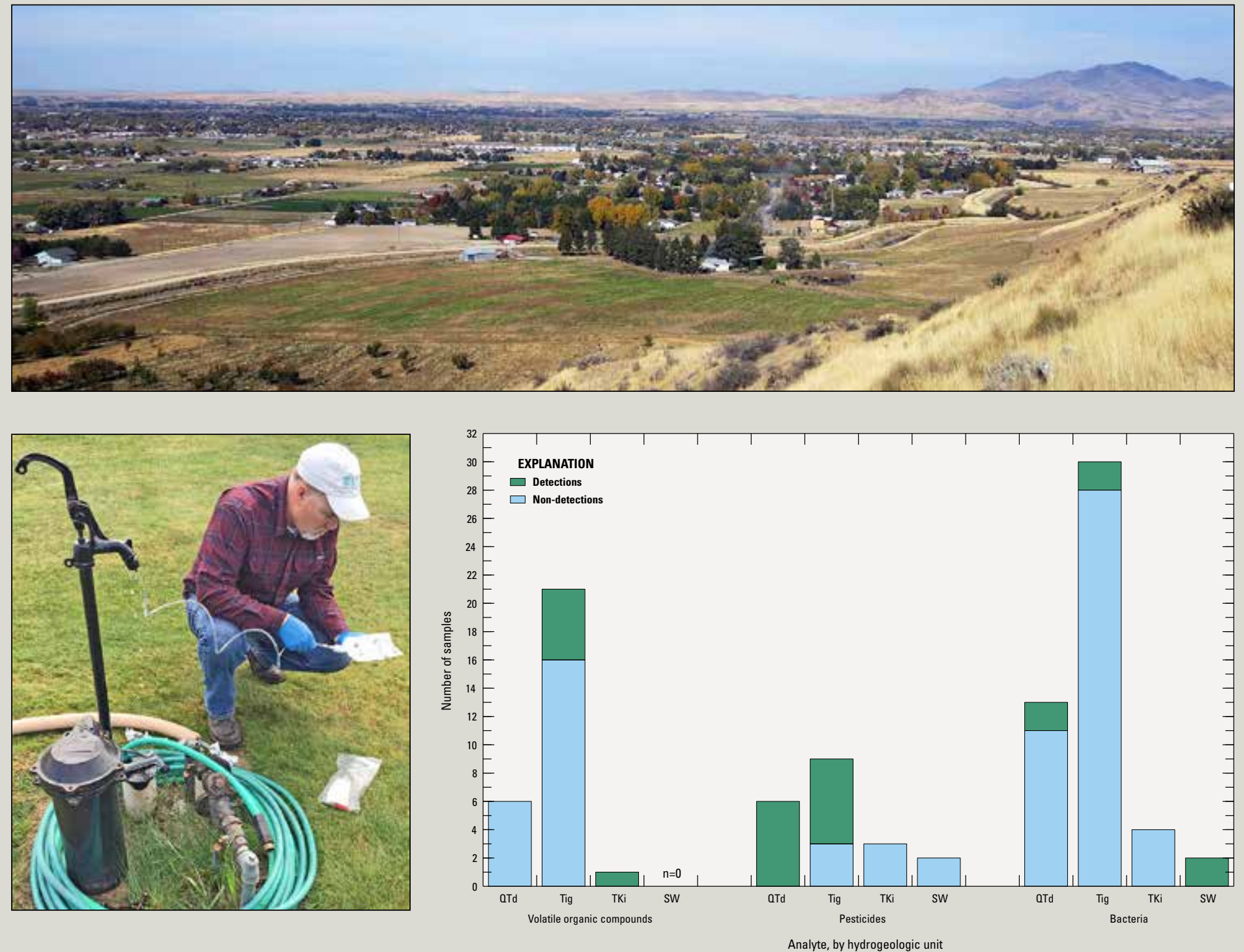

Scientific Investigations Report 2016-5170 
Cover:

Top: View of the Emmett Valley looking north from Freezeout Hill. Photograph by J.R. Bartolino, U.S. Geological Survey, October 22, 2016.

Bottom left: A U.S. Geological Survey hydrologist collects a dissolved gas sample at a private well in Emmett. Photograph by J.R. Bartolino, U.S. Geological Survey, September 16, 2015.

Bottom right: Representation of volatile organic compounds, pesticides, and bacteria detections in groundwater and surface water, Gem County, southwestern Idaho, September-November 2015. 


\section{Ambient Water Quality in Aquifers Used for Drinking-Water Supplies, Gem County, Southwestern Idaho, 2015}

By James R. Bartolino and Candice B. Hopkins

Prepared in cooperation with Gem County, Idaho, and the Idaho Department of Environmental Quality

Scientific Investigations Report 2016-5170 


\title{
U.S. Department of the Interior SALLY JEWELL, Secretary
}

\section{U.S. Geological Survey Suzette M. Kimball, Director}

\author{
U.S. Geological Survey, Reston, Virginia: 2016
}

For more information on the USGS - the Federal source for science about the Earth, its natural and living resources, natural hazards, and the environment—visit http://www.usgs.gov or call 1-888-ASK-USGS.

For an overview of USGS information products, including maps, imagery, and publications, visit http://store.usgs.gov/.

Any use of trade, firm, or product names is for descriptive purposes only and does not imply endorsement by the U.S. Government.

Although this information product, for the most part, is in the public domain, it also may contain copyrighted materials as noted in the text. Permission to reproduce copyrighted items must be secured from the copyright owner.

Suggested citation:

Bartolino, J.R., and Hopkins, C.B., 2016, Ambient water quality in aquifers used for drinking-water supplies, Gem County, southwestern Idaho, 2015: U.S. Geological Survey Scientific Investigations Report 2016-5170, 33 p., https://doi.org/10.3133/sir20165170.

ISSN 2328-0328 (online) 


\section{Contents}

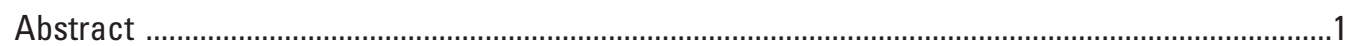

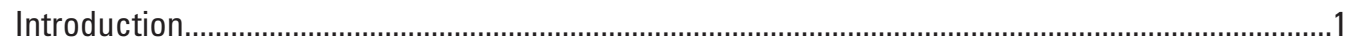

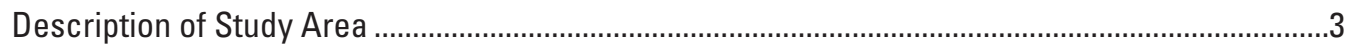

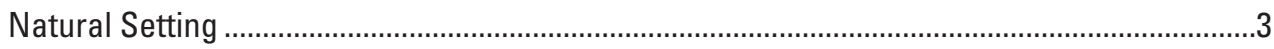

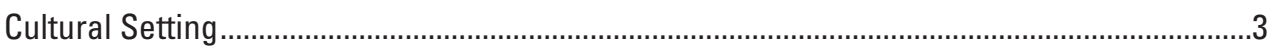

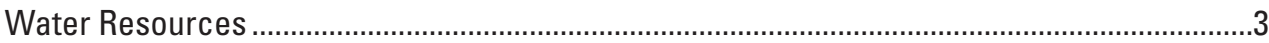

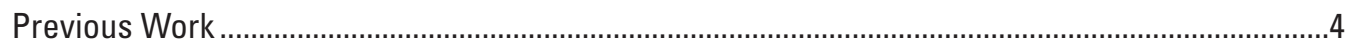

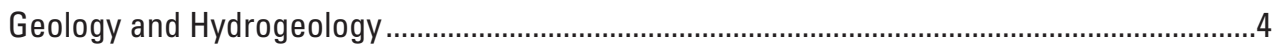

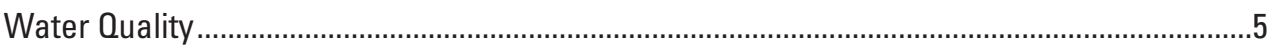

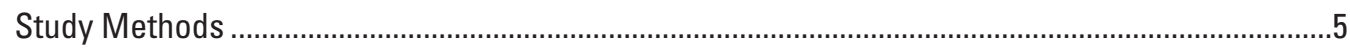

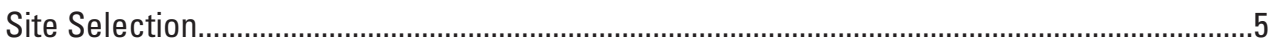

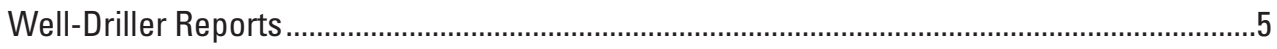

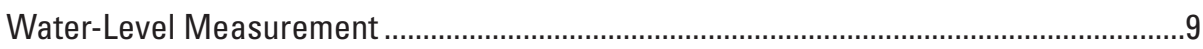

Groundwater-Level Map......................................................................................

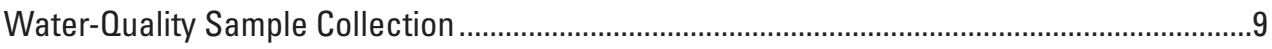

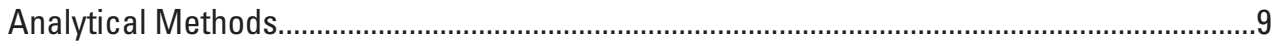

Quality Assurance and Quality Control .................................................................................

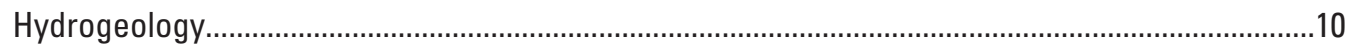

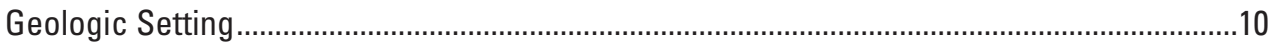

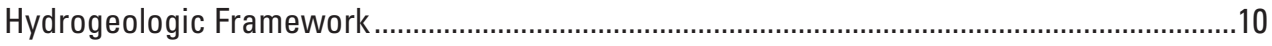

Quaternary-Tertiary Deposits Hydrogeologic Unit (OTd) .............................................12

Tertiary Idaho Group Hydrogeologic Unit (Tig) ........................................................12

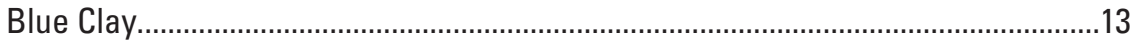

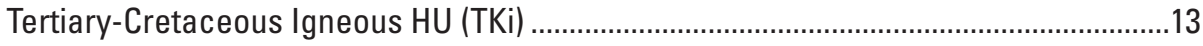

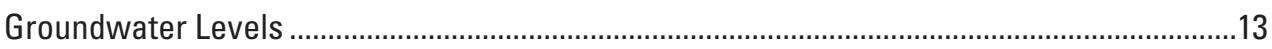

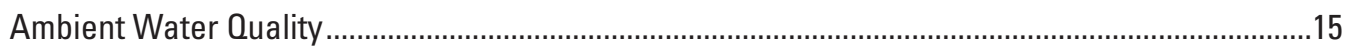

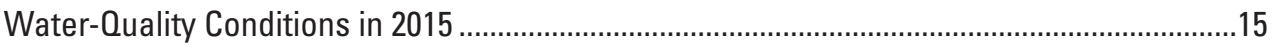

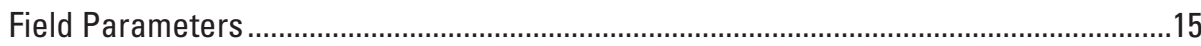

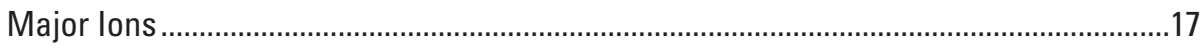

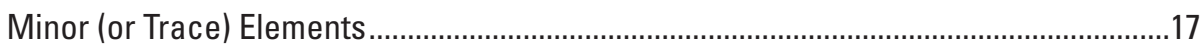

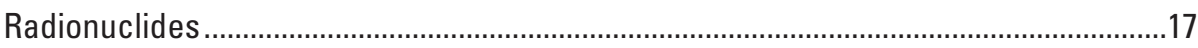

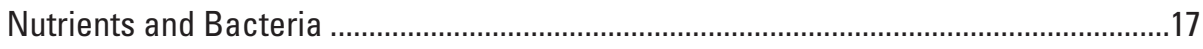

Volatile Organic Compounds and Pesticides .................................................................18

Oxygen-18 and Deuterium of Water ……………………................................................20

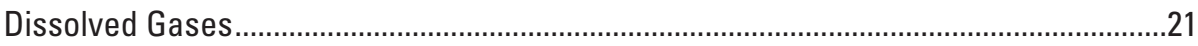

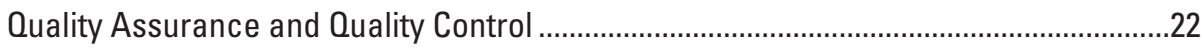

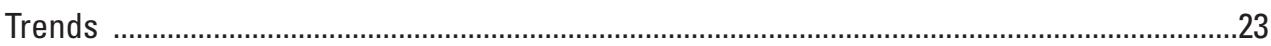

Additional Needs for Groundwater-Quality Monitoring ..............................................................25

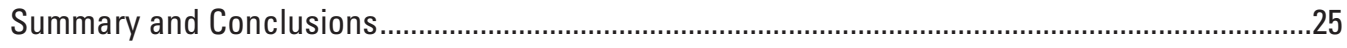

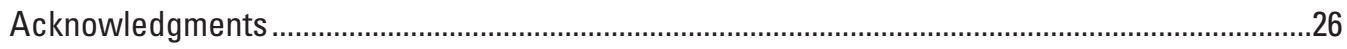

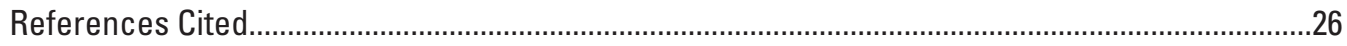

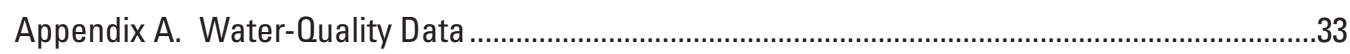




\section{Figures}

1. Map showing locations of communities, selected U.S. Geological Survey (USGS) streamgages, and other features, Gem County, southwestern Idaho .2

2. Map showing groundwater and surface-water quality sites sampled in Gem County, southwestern Idaho, September-November 2015

3. Map showing water-level altitudes of selected wells, Gem County, southwest Idaho, September-November 2015

4. Boxplots showing distribution of dissolved oxygen, arsenic, and nitrate concentrations in groundwater and surface water, Gem County, southwestern Idaho, September-November 2015

5. Graph showing volatile organic compounds, pesticides, and bacteria detections in groundwater and surface water, by hydrogeologic unit, Gem County, southwestern Idaho, September-November 2015

6. Graph showing stable isotopes of oxygen and hydrogen in groundwater and surface water samples, Gem County, southwestern Idaho, SeptemberNovember 2015.

7. Graph showing stable isotopes of methane in groundwater collected from six wells, southwestern Gem County, Idaho, September-November 2015

8. Graphs showing nitrate and arsenic concentrations in groundwater in selected wells, Gem County, southwestern Idaho, 1992-2015

\section{Tables}

1. Sampling sites and characteristics, alternate names, and location information for groundwater and surface-water sampling sites, Gem County, southwestern Idaho, September-November 2015

2. Geologic time scale with stratigraphic and hydrogeologic units of the Gem County, Idaho, area

3. Inorganic and nutrient material in groundwater collected from selected wells, Gem County, southwestern Idaho, 2015

4. Pesticides and volatile organic compounds detected in groundwater, Gem County, southwestern Idaho, 2015

5. Slope and $y$-intercept values for meteoric water line equations used in this report .....20

6. Dissolved methane concentrations in groundwater by hydrogeologic unit, Gem County, Idaho, 2015. 


\section{Conversion Factors}

U.S. customary units to International System of Units

\begin{tabular}{lcl}
\hline \multicolumn{1}{c}{ Multiply } & By & \multicolumn{1}{c}{ To obtain } \\
\hline inch (in.) & Length & \\
foot (ft) & 2.54 & centimeter $(\mathrm{cm})$ \\
mile (mi) & 0.3048 & meter $(\mathrm{m})$ \\
& 1.609 & kilometer $(\mathrm{km})$ \\
\hline square mile $\left(\mathrm{mi}^{2}\right)$ & Area & \\
\hline & 2.590 & square kilometer $\left(\mathrm{km}^{2}\right)$ \\
\hline liter $(\mathrm{L})$ & Volume & quart $(\mathrm{qt})$ \\
\hline & 1.057 & liter per second $(\mathrm{L} / \mathrm{s})$ \\
\hline gallon per minute $(\mathrm{gal} / \mathrm{min})$ & Flow rate & cubic meter per second $\left(\mathrm{m}^{3} / \mathrm{s}\right)$ \\
\hline cubic foot per second $\left(\mathrm{ft}{ }^{3} / \mathrm{s}\right)$ & 0.06309 & \\
\hline picocurie per liter $(\mathrm{pCi} / \mathrm{L})$ & 0.02832 & becquerel per liter $(\mathrm{Bq} / \mathrm{L})$ \\
\hline
\end{tabular}

Temperature in degrees Celsius $\left({ }^{\circ} \mathrm{C}\right)$ may be converted to degrees Fahrenheit $\left({ }^{\circ} \mathrm{F}\right)$ as follows:

$$
{ }^{\circ} \mathrm{F}=\left(1.8 \mathrm{x}^{\circ} \mathrm{C}\right)+32 .
$$

Temperature in degrees Fahrenheit $\left({ }^{\circ} \mathrm{F}\right)$ may be converted to degrees Celsius $\left({ }^{\circ} \mathrm{C}\right)$ as follows:

$$
{ }^{\circ} \mathrm{C}=\left({ }^{\circ} \mathrm{F}-32\right) / 1.8 \text {. }
$$

\section{Datums}

Vertical coordinate information is referenced to the North American Vertical Datum of 1988 (NAVD 88)

Horizontal coordinate information is referenced to the North American Datum of 1983 (NAD 83)

Altitude, as used in this report, refers to distance above the vertical datum.

\section{Supplemental Information}

Specific conductance is given in microsiemens per centimeter at 25 degrees Celsius ( $\mu \mathrm{S} / \mathrm{cm}$ at $25^{\circ} \mathrm{C}$ ).

Concentrations of chemical constituents in water are given either in milligrams per liter (mg/L) or micrograms per liter $(\mu \mathrm{g} / \mathrm{L})$. 



\title{
Ambient Water Quality in Aquifers Used for Drinking- Water Supplies, Gem County, Southwestern Idaho, 2015
}

\author{
By James R. Bartolino and Candice B. Hopkins
}

\section{Abstract}

In recent years, the rapid population growth in Gem County, Idaho, has been similar to other counties in southwestern Idaho, increasing about 54 percent from 1990 to 2015. Because the entire population of the study area depends on groundwater for drinking water supply (either from self-supplied domestic, community, or municipal-supply wells), this population growth, along with changes in land use (including potential petroleum exploration and development), indicated to the public and local officials the need to assess the quality of groundwater used for human consumption. To this end, the U.S. Geological Survey, in cooperation with Gem County and the Idaho Department of Environmental Quality, assessed the quality of groundwater from freshwater aquifers used for domestic supply in Gem County. A total of 47 domestic or municipal wells, 1 spring, and 2 surface-water sites on the Payette River were sampled during September 8November 19, 2015. The sampled water was analyzed for a variety of constituents, including major ions, trace elements, nutrients, bacteria, radionuclides, dissolved gasses, stable isotopes of water and methane, and either volatile organic compounds (VOCs) or pesticides.

To better understand analytical results, a conceptual hydrogeologic framework was developed in which three hydrogeologic units were described: Quaternary-Tertiary deposits (QTd), Tertiary Idaho Group rocks (Tig), and Tertiary-Cretaceous igneous rocks (TKi). Water levels were measured in 30 wells during sampling, and a groundwaterlevel altitude map was constructed for the QTd and Tig units showing groundwater flow toward the Emmett Valley and Payette River.

Analytical results indicate that groundwater in Gem County is generally of good quality. Samples collected from two wells contained water with fluoride concentrations greater than the U.S. Environmental Protection Agency (EPA) Maximum Contaminant Level (MCL) of 4 milligrams per liter $(\mathrm{mg} / \mathrm{L})$, six wells contained arsenic at concentrations greater than the EPA MCL of 10 micrograms per liter, and a sample from one well exceeded the MCL of 15 picocuries per liter for alpha particles. Although previous samples collected from some wells in Gem County contained nitrate concentrations greater than the MCL of $10 \mathrm{mg} / \mathrm{L}$, the largest concentration detected in the current study was $5.2 \mathrm{mg} / \mathrm{L}$. Total coliform bacteria was detected in four groundwater samples.

Three volatile organic compounds (VOCs) were detected in samples collected from five wells, and five compounds of the triazine class of herbicides were detected in samples from five wells; no concentrations were greater than applicable EPA MCLs. Methane was detected in samples from 36 wells, with the concentration in 1 well large enough to be considered an explosion hazard by U.S. Office of Surface Mining guidelines. Stable isotope signatures of methane in six samples suggest that naturally occurring methane in Gem County is probably of both thermogenic and biogenic origin.

\section{Introduction}

Rapid population growth in Gem County, Idaho, in recent years is similar to other counties in southwestern Idaho (fig. 1). Gem County population increased from about 11,000 to 16,900 (54 percent) from 1990 to 2015 (Forstall, 1995; U.S. Census Bureau, 2016). Because the entire population of the study area depends on groundwater for drinking water supply (either from self-supplied domestic, community, or municipal-supply wells), this population growth, along with changes in land use (including potential petroleum exploration and development), indicated to officials the need for a water-quality assessment of groundwater used for human consumption.

Several studies (described in section, "Previous Work") have addressed specific water-related issues or aspects in selected areas of Gem County, but a comprehensive evaluation of groundwater-quality in the county was needed to address current concerns about the effects of development and the potential effects of continued growth and petroleum-extraction activities. In 2015, the U.S. Geological Survey (USGS), in cooperation with Gem County and the Idaho Department of Environmental Quality (IDEQ), began studying the quality of groundwater from freshwater aquifers used for domestic supply in Gem County. The results of that study, which are summarized in this report, will assist water-resource managers and planners in the management of water resources and the development of a long-term water-management plan for the county. 


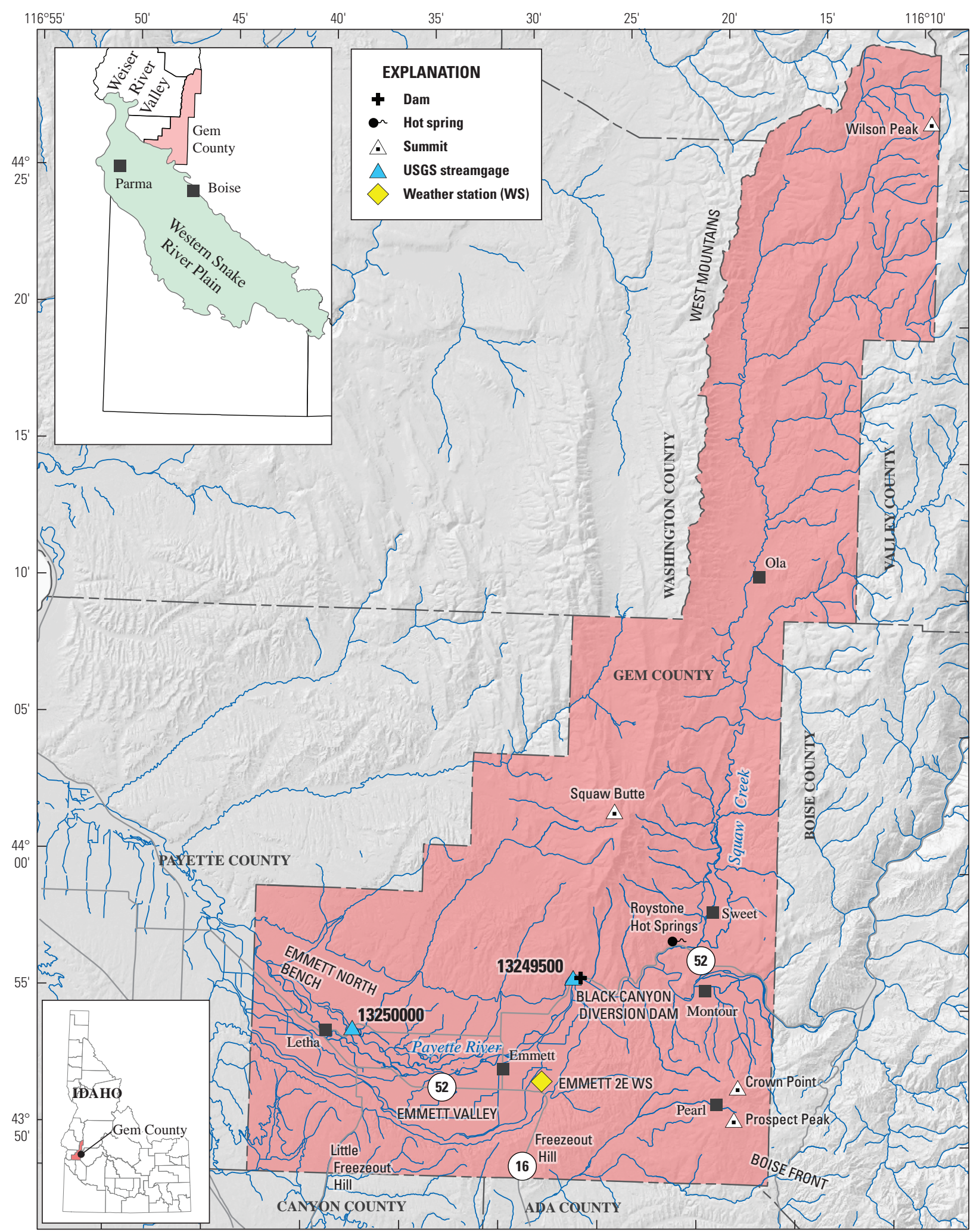

Base map from Idaho Geospatial Data Clearinghouse, 2004 U.S. Geological Survey digital data, 1999, ESRI, 2000, 2016 Idaho Legislative Services Office, 2001, Idaho Department of Water Resources, 1990, Idaho Transverse Mercator,

North American Datum of 1983

Figure 1. Locations of communities, selected U.S. Geological Survey (USGS) streamgages, and other features, Gem County, southwestern Idaho. 
This report describes a water-quality assessment of groundwater from freshwater aquifers used for domestic supply in Gem County, Idaho. For the assessment, 47 domestic and municipal wells, 1 spring, and 2 surface-water sites on the Payette River were sampled September 8 through November 19, 2015. As part of the assessment, a basic hydrogeologic framework was compiled, which includes a classification of the water-bearing rocks of the study area and a groundwater-level map using water levels measured during sampling. The report also describes the potential for additional water-quality monitoring.

\section{Description of Study Area}

\section{Natural Setting}

Gem County, with a land area of 566 square miles $\left(\mathrm{mi}^{2}\right)$, is located in southwestern Idaho (fig. 1). Most of the southern part of the county is in the Emmett Valley. Consisting of the incised lowlands of the Payette River, the Emmett Valley extends from Black Canyon Diversion Dam (altitude 2,480 ft) to about the boundary with Payette County to the west (2,240 ft) (fig. 1). Additional lowlands are in the eastern part of the county in the valley of Squaw Creek (2,560 ft at Sweet), and a relatively flat area near Montour (2,520 ft) (fig. 1). The panhandle-shaped northern part of the county is in the Squaw Creek drainage basin, which is bounded by mountains including Squaw Butte (5,870 ft) and Wilson Peak (7,860 ft) in the West Mountains. In the southeastern part of the county, mountains of the eastern Boise Front include Crown Point (5,160 ft) and Prospect Peak (4,870 ft). A 400-500-ft escarpment along the southern boundary of Gem County separates the Emmett Valley to the north from uplands to the south. These uplands separate the Boise River and Payette River drainage basins and are referred to as the Boise ValleyPayette Valley interfluve in this report.

The climate of Gem County is categorized into four of the Köppen climate classifications. The classifications range from, in a north-to-south direction, cold continental subarctic or boreal climates with cold and dry summers (Dsc), hemiboreal climates with warm and dry summers (Dsb), continental climates with hot and dry summers (Dsa), and semiarid cold steppe climate (BSk) (Lutgens and Tarbuck, 1982; Idaho State Climate Services, 1999).

The Emmett 2E National Weather Service station (fig. 1) has a period of record from October 1906 to the present (November 2016) (National Oceanic and Atmospheric Administration, 2016). From 1916 to 2015, mean annual air temperature at the station was $51.4^{\circ} \mathrm{F}$; the coldest month in the study area was January, with a mean low air temperature of $21.5^{\circ} \mathrm{F}$; the warmest month typically was July, with a mean high air temperature of $92.5^{\circ} \mathrm{F}$. The mean first-freeze $\left(32.5^{\circ} \mathrm{F}\right)$ date was October 7 and the mean last-freeze $\left(32.5^{\circ} \mathrm{F}\right)$ date was May 6. Mean annual precipitation which combines rainfall and snowfall (as snow water equivalent) was 12.6 in., and mean total snowfall was 12.5 in. July and August typically were the driest months; December and January were the wettest. The greatest monthly average snow depth of $1 \mathrm{in}$. typically occurred in January (Western Regional Climate Center, 2016).

Six level-IV ecoregions (areas of generally similar ecosystems) occur over the approximately 5,600 ft of relief in Gem County. The ecoregions range from, in a north-to-south direction, the High Idaho Batholith (16h), Southern Forested Mountains (16k), Semiarid Foothills (12f), Foothill ShrublandGrasslands (16f), Unwooded Alkaline Foothills (12j), and Treasure Valley (12a) ecoregions (McGrath and others, 2002).

\section{Cultural Setting}

Land ownership in Gem County is mostly private, with about 37 percent of the total area owned by the Federal Government. Most of this Federal land is managed by the Bureau of Land Management and the Payette National Forest (U.S. Geological Survey, 2014).

The estimated population of Gem County was 16,852 in July 2015 (U.S. Census Bureau, 2016a). Emmett, the only city in Gem County (fig. 1), had a population of 6,599 in July 2014 (U.S. Census Bureau, 2016b). Unincorporated communities are Letha, Montour, Ola, Pearl, and Sweet (fig. 1). Population is concentrated in the Emmett Valley and lower Squaw Creek drainage.

Agriculture and related industries (including wood products) have historically been the largest employers in Gem County (Savage, 1961; Parliman, 1986). In recent years, however, service and professional jobs have become the most common, followed by farming, government, manufacturing, construction, and mining (Gardner, 2008; City of Emmett and Gem County, 2014; Idaho Department of Labor, 2016). In 2007, 64 percent of Gem County workers commuted to jobs outside the county, primarily to Ada and Canyon Counties to the south (fig. 1) (Gardner, 2008).

\section{Water Resources}

The Payette River is the major surface-water feature in Gem County. Nearly the entire county is in the Payette River drainage basin, but a small area along the southern boundary drains to the Boise River drainage basin. At the county's western boundary, the upstream drainage area of the Payette River is about 2,900 $\mathrm{mi}^{2}$. In the county, a number of small perennial and ephemeral streams drain to the river. About $5 \mathrm{mi}$ northeast of Emmett on the Payette River, the Black Canyon Diversion Dam impounds Black Canyon Reservoir and diverts water into the Black Canyon Canal (south of the river) and the Emmett Irrigation District Canal (north of the river) (fig. 1, fig. 3). Additional water is diverted from the Payette River downstream of the dam into the Last Chance Ditch and Farmer's Cooperative Canals (fig. 3). All of these canals feed 
a well-developed network of irrigation canals in the Emmett Valley and downstream in Canyon and Payette Counties. These canals typically are used during the mid-April through late-September irrigation season.

Wells in the study area provide groundwater for irrigation, domestic and municipal supply, industry, and livestock. Groundwater occurs under both unconfined and confined conditions; some wells flow in areas where the potentiometric head is above land surface. According to well-driller reports maintained by the Idaho Department of Water Resources (IDWR), groundwater levels range from above land surface to about $700 \mathrm{ft}$ below land surface, and well yields range from nonproductive to 2,280 gallons per minute (gal/min). Groundwater and surface water are closely connected in the Emmett Valley; groundwater levels are typically lowest before the beginning of irrigation season and highest near the end of irrigation season as surface-water diversions cease.

Nonthermal springs provide water for domestic water supply in areas underlain by basalt north of the Payette River. Roystone Hot Springs, about $2 \mathrm{mi}$ southwest of Sweet, also likely issues from basalt (fig. 1) (Lewis and Young, 1980; Young, 1985). These thermal springs were developed by 1909 (Roystone Hot Springs, 2016). Multiple domestic wells near Emmett are classified as low-temperature geothermal (between 85 and $212^{\circ} \mathrm{F}$ ) by the IDWR, and several wells greater than $1,000 \mathrm{ft}$ in depth produce water as much as $268^{\circ} \mathrm{F}$ (Dennis Owsley, Idaho Department of Water Resources, written commun., August 2, 2016).

\section{Previous Work}

\section{Geology and Hydrogeology}

Because the southern and western areas of Gem County are on the northern margin of the western Snake River Plain, many publications concerning it, Gem County, the Boise area, and the Treasure Valley pertain to this report. The earliest descriptions of the geology of the western Snake River Plain were associated with the second John C. Frémont expedition (1843-44), followed by the Fortieth Parallel Survey of Clarence King (1867-72), and subsequent workers (Malde and Powers, 1962).

The geology and mineral resources of Ada and Canyon Counties were described in Savage (1958) and Gem and Payette Counties in Savage (1961). Malde and Powers (1962) described the upper Cenozoic stratigraphy of the western Snake River Plain, thus clarifying or establishing many of the geologic unit names in current use. In an unpublished geologic map Burnham and Wood (1992) proposed several new geologic names for upper Idaho Group sediments in the northern part of the western Snake River Plain. This nomenclature has been used by Wood and Clemmons (1982),
Wood (2004), Squires and others (2007), and other authors. Wood $(1994,2004)$ discussed the geology of Idaho Group sediments in the western Snake River Plain.

The USGS Snake River Plain Regional Aquifer System Analysis (RASA) program described various aspects of the hydrogeology of the eastern and western Snake River Plain in several publications. Western Snake River Plain RASA publications include depth to water maps (1980 conditions) (Lindholm and others, 1983; 1988), a water budget (Kjelstrom, 1995), a geohydrologic framework (Whitehead, 1986), a map of irrigated lands and land use (1980 conditions) (Lindholm and Goodell, 1986), and steady-state and transient MODFLOW models (Newton, 1991). Following the RASA, Maupin (1991) used 1980-88 data to construct a composite depth-to-water map for the western Snake River Plain, including much of the study area.

Bond and others (2011) is the formal release of a report completed in 1983 that discusses petroleum geology in the 3,000 $\mathrm{mi}^{2}$ Weiser structural basin (the study area lies on the southeastern edge of this basin) and surrounding area. Nearly all of Gem County is in their study area and the report includes sections on geology, geologic history, and hydrocarbon potential.

The Boise Valley (or Treasure Valley, or lower Boise River basin) forms much of the western part of the western Snake River Plain. Although it does not include most of Gem County, much of the hydrogeology is similar and thus relevant. The Treasure Valley Hydrologic Project characterized groundwater and surface-water resources. This project was led by the IDWR in cooperation with numerous other government and private entities. Project reports included the hydrogeologic framework of Squires and others (1992), a groundwater-flow model by Petrich (2004a), and a number of other reports that are listed in Petrich (2004b).

Residential development of varying scale and density has occurred in the upland that forms the divide between the Boise and Payette Rivers (the Boise Valley-Payette Valley interfluve). Several reports, including Baker (1991), SPF Water Engineering, LLC (2004), and Squires and others (2007), have addressed groundwater in this interfluve south of the study area. Additional supporting material including geophysics, water levels, aquifer tests, groundwater-flow models, and geochemical data are available in SPF Water Engineering, LLC (2004) and Squires and others (2007).

The geology and hydrogeology of Payette County (fig. 1) is similar to that of Gem County. Savage (1961), Deick and Ralston (1986), and Baldwin and Wicherski (1994) described the groundwater resources of Payette County.

The most recent statewide geologic map of Idaho was compiled by Lewis and others (2012). The Idaho Geological Survey is currently (2016) mapping parts of the study area at a scale of 1:24,000, including the Montour quadrangle (Lewis and others, 2016). 


\section{Water Quality}

In 2000, the IDEQ defined and ranked 33 Nitrate Priority Areas (NPAs) where more than 25 percent of the wells had nitrate concentrations greater than $5 \mathrm{mg} / \mathrm{L}$ (Parliman, 2002). These 33 areas were combined into 25 areas that were assessed for statistically significant trends in nitrate concentrations for different periods of time between 1961 and 2001 (Parliman, 2002). The IDEQ designated the Emmett North Bench (fig. 1) as an NPA in 2008 (Idaho Department of Environmental Quality, 2008). Neely (2008) updated Parliman's (2002) trend analysis of NPAs for 1994-2000 and 2001-07. The Emmett North Bench NPA showed no nitrate trend for either period. A subsequent update by Neeley (2013) for two additional periods (2002-06 and 2007-11) still showed no discernible trend for the Emmett North Bench NPA.

The Idaho State Department of Agriculture (ISDA) started a regional project in 1998 to examine groundwater quality in Payette and Gem Counties (Idaho State Department of Agriculture, 2010a, 2010b). Of the 18 wells sampled for pesticides in Gem County in 1998 and 1999, two contained atrazine and its degradates (Idaho State Department of Agriculture, 2010a). In 2002, atrazine and its degradates were detected in samples from two of the same wells and prometon was detected in a third (Atlakson, 2006; Idaho State Department of Agriculture, 2010a). In 2005, two wells were sampled, and atrazine and its degradates were detected in one (Atlakson, 2006; Carlson and Atlakson, 2007; Idaho State Department of Agriculture, 2010a). In 2006, no pesticides were detected in Gem County (Bahr and Elliott, 2009; Idaho State Department of Agriculture, 2010a).

Several publications have addressed water quality in the Payette River basin as a whole. Lewis and Young (1980) characterized the water quality of thermal springs. Parliman (1986) collected water-quality and hydrologic data for 74 wells in 1982; 20 of these wells were in Gem County. Steed and others (1993) described the water quality of the Snake-Payette Rivers hydrologic unit that included parts of Gem County. Their summary included data from the Idaho Farm Bureau, IDEQ, and USGS. Wicherski (2000) examined groundwater quality near Fruitland, Idaho (23 mi west of Emmett in Payette County).

Samples were collected in three wells in Gem County during 2004 as part of the IDWR Statewide Ambient Ground Water Quality Monitoring Program (Campbell, 2006). Two of the wells contained arsenic at concentrations greater than $10 \mu \mathrm{g} / \mathrm{L}$ and 1,4-dichlorobenzene, a household product, was detected in the third well. Since 1991, arsenic and (or) the pesticide compounds desethyl atrazine (an atrazine degradate), metolachlor, metribuzin, tebuthiuron, and trifluralin have been detected in the same three wells (Campbell, 2006).

Kellogg and others (1996) sampled 14 wells in the immediate vicinity of Emmett and determined that 3 wells within $50 \mathrm{ft}$ of each other contained Escherichia coli (E. coli). Subsequent tracer tests were inconclusive as to the E. coli source.
Elliot (2015) reported results for eight wells sampled in 2013 for the Sand Hollow Creek project (part of the Emmett North Bench NPA). Total coliform was detected in samples from two wells; a sample from one well had a nitrate concentration greater than $10 \mathrm{mg} / \mathrm{L}$. Elliot (2015, p. 4) concluded that nitrogen isotopes from samples collected between 2002 and 2013 "indicate human or animal waste is contributing nitrate to the ground water supplying a dairy production well."

\section{Study Methods}

\section{Site Selection}

Groundwater-sampling sites were selected for an equal spatial distribution throughout Gem County with a preference to sites that had been previously sampled. Sampling sites were selected to represent a wide-spatial distribution and the three main hydrogeologic units of the study area (as described in section, "Hydrogeologic Framework"). Wells sampled represent both private and public-supply wells used for drinking water. Wells were inventoried and water levels were measured in accordance with USGS Office of Ground Water Technical Procedures (Cunningham and Schalk, 2011). Surface-water sites were selected to represent the water quality of the Payette River during non-irrigation season in Gem County. For ease of display, sampling sites were assigned a short site number for the current report based on the type of site and the main hydrogeologic unit of well completion (discussed in section, "Hydrogeologic Framework"). Table 1 shows this site number and the corresponding USGS site identifier and well name. A total of 47 wells, 1 spring, and 2 surface-water sites on the Payette River were sampled for the study (fig. 2, table 1). Springs are considered groundwater in this report.

\section{Well-Driller Reports}

The primary sources of hydrogeologic data for this study were well-driller reports maintained by the Idaho Department of Water Resources (IDWR) and made available through an online database (Idaho Department of Water Resources, 2016a). This IDWR database contains "most of the well-driller reports from J uly 1987 to present," but because such reports were requested, but not required, by the IDWR prior to 1953, the database does not contain reports for all wells drilled in the study area (Castellin and Winner, 1975; Idaho Department of Water Resources, 2016a). The database does include, however, reports for many wells drilled before 1987 (the oldest well in the database for the study area was drilled in 1944). Currently (May 2016), the database contains 3,921 well-driller reports (also known as drillers' logs) for Gem County. 


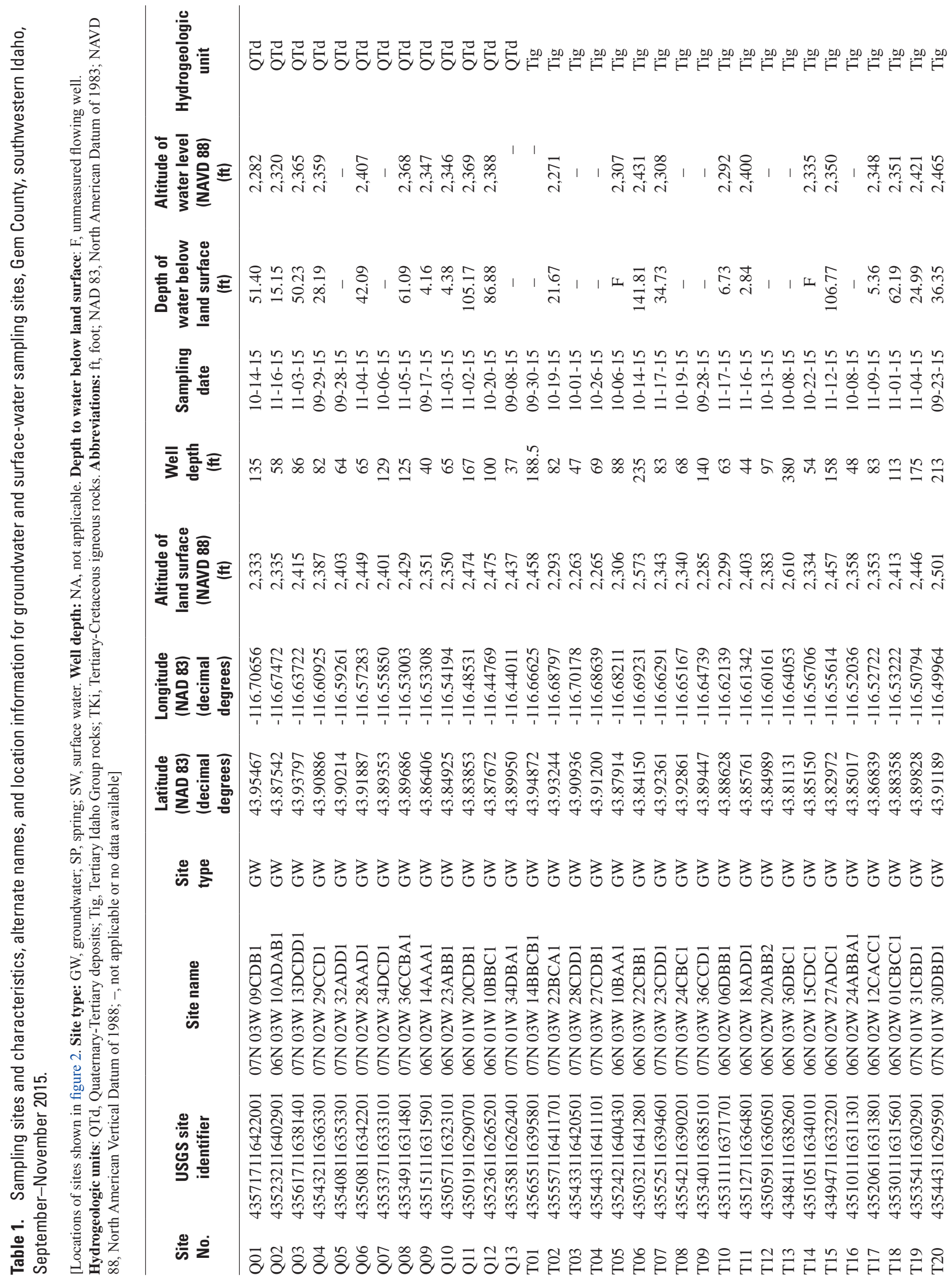




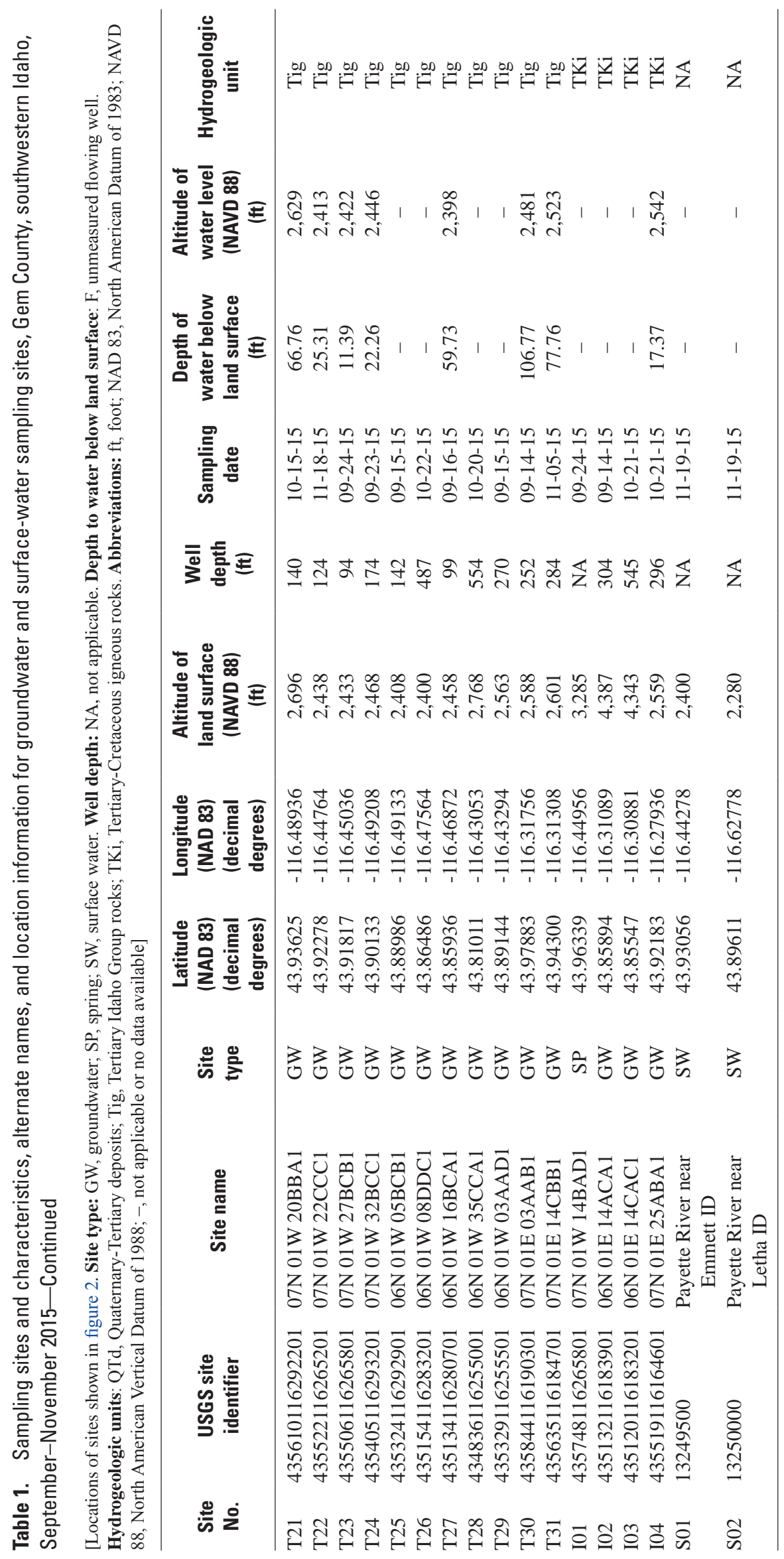




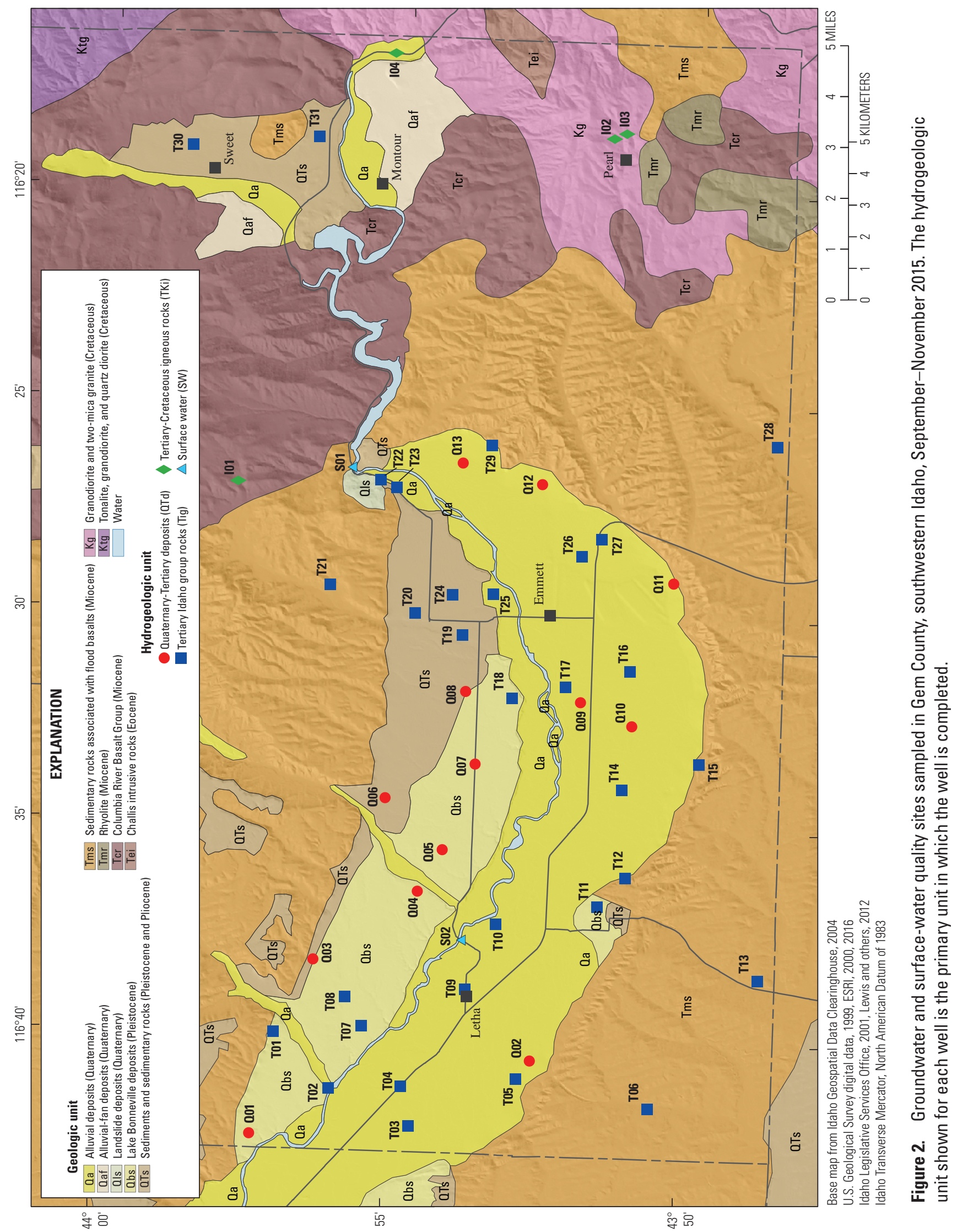


Well locations in the well-driller reports historically have been reported using the Public Land Survey System (PLSS) to the 160-, 40-, or 10-acre tract level. In the absence of a more-precise location, the IDWR assigns a latitude and longitude corresponding to the center of the smallest assigned tract to denote the well location. Consequently, reported well locations may vary from actual locations. The quality of location and lithologic information from well-driller reports can be highly variable.

\section{Water-Level Measurement}

Water levels were measured in 30 of the 47 wells sampled during September 8-November 18, 2015, in accordance with USGS methods (Cunningham and Schalk, 2011). In non-flowing wells, water levels were measured using either a steel tape or calibrated-electric tape. Water levels in 17 wells were not measured because well-head construction did not allow access.

\section{Groundwater-Level Map}

The groundwater-level altitude map (fig. 3) was produced using ArcMap ${ }^{\mathrm{TM}} 10.2$ geographic information system (GIS) software (Environmental Systems Research Institute, 2016). The map was created by evaluating water-level data in ArcMap ${ }^{\mathrm{TM}}$ using the "Kriging" interpolation tool to create a raster surface for the map (settings were ordinary kriging with a spherical semivariogram model). The "Contour" tool was then used to create $50-\mathrm{ft}$ interval contour lines representing water-level altitude (using a Z-factor of 1). Contour lines that were artifacts of the interpolation tool were eliminated or adjusted and contour lines in areas of uncertainty were dashed. Two flowing wells that were not measured (T05 and T14) were assigned a water level of $1.0 \mathrm{ft}$ above land surface and were included in contour generation (table 1, fig. 3).

\section{Water-Quality Sample Collection}

Water-quality samples were collected during a 3-month period from September 8 to November 19, 2015, to reduce seasonal variability. Groundwater samples were collected after water-level measurement and a minimum of three well-casing volumes were pumped from the well. Surface-water samples were collected using the depth-integrated equal-widthincrement method (U.S. Geological Survey, variously dated) after which stream discharge was measured.

Field parameters (dissolved oxygen, $\mathrm{pH}$, specific conductance, temperature, and alkalinity) were measured at all sampling sites in accordance with USGS procedures (Olson and Norris, 2005; U.S. Geological Survey, variously dated). Groundwater samples were conveyed from the sampling point through Teflon tubing into a protected sampling chamber; sampling equipment was cleaned between sampling sites with methanol, Liquinox ${ }^{\circledR}$, and deionized water according to USGS field methods protocol (Wilde, 2004). Dissolvedgas samples were collected at the sampling point using IsoFlask ${ }^{\circledR}$ containers supplied by Isotech Laboratories (Isotech Laboratories, Inc., 2014).

\section{Analytical Methods}

The Idaho Department of Health and Welfare Laboratory in Boise, Idaho, analyzed total coliform bacteria and E. coli samples within 24 hours of collection using the Quanti-Tray ${ }^{\circledR}$ technique (U.S. Geological Survey, variously dated, chapter 7.1.3E). Samples were analyzed for the count of total coliform and E. coli bacteria, and results represent a count of the most probable number of colonies per 100 milliliters $(\mathrm{mL})$. Dissolved-gas samples were analyzed using chromatographic separation by Isotech Laboratories in Champaign, Illinois. Samples containing dissolved methane at or greater than $0.1 \mathrm{mg} / \mathrm{L}$ were analyzed for the carbon isotopic ratio $\left({ }^{13} \mathrm{C} /{ }^{12} \mathrm{C}\right)$ and hydrogen isotope ratio $\left({ }^{2} \mathrm{H} /{ }^{1} \mathrm{H}\right)$ of methane using combustion and dual-inlet isotope ratio mass spectrometry.

Stable-isotope ratios of oxygen and hydrogen were analyzed at the USGS Reston Stable Isotope Laboratory in Reston, Virginia. Samples were collected in $60 \mathrm{~mL}$ glass bottles with Poly-Seal ${ }^{\circledR}$ caps. Hydrogen-isotope-ratio analyses were performed using the hydrogen equilibration technique (Coplen and others, 1991). Results for stable isotopes are in units of per mil (\%o, parts per thousand), and expressed in delta notation $(\delta)$ as derived from comparing the sample to the Vienna Standard Mean Ocean Water (VSMOW) (Coplen, 1996). The two standard deviation (2- $\sigma$ ) accuracy of oxygen and hydrogen isotope results were 0.2 and $2 \%$, respectively (Révész and Coplen, 2008a, 2008b).

All other constituents were analyzed at the USGS National Water-Quality Laboratory (NWQL) in Lakewood, Colorado with the standard analytical techniques described in Fishman and Friedman (1989). All data from both USGS and outside laboratories are stored in the USGS National Water Information System database (U.S. Geological Survey, 2016a) and are provided in appendix A.

\section{Quality Assurance and Quality Control}

Water samples were collected for this study in accordance with the quality-assurance plan of the USGS Idaho Water Science Center (M.W. Hardy, U.S. Geological Survey, written commun., November 7, 2016). Field meters used in this study were calibrated in the field at the beginning of each day and are checked annually against known reference standards.

Standard procedures used by the NWQL for internal sample handling and quality assurance are described by Friedman and Erdmann (1982), Pritt and Raese (1995), and Maloney (2005). The NWQL participates in a blind-sample program in which standard reference water samples prepared by the USGS Branch of Quality Systems are routinely inserted into the sample line for each analytical method at a frequency 
proportional to the sample load (U.S. Geological Survey, 2016b). The laboratory also participates in external evaluation studies and audits with several outside agencies to assess analytical performance.

The quality of analytical results reported for water samples was evaluated using quality-control samples that provided quantitative information on the precision and bias of the overall field and laboratory process. Blank and sequential replicate samples were collected as quality-control samples. Field blanks and equipment blanks are aliquots of certified trace-element, VOC, and (or) pesticide-free deionized water processed through the sampling equipment used to collect environmental samples. These blanks were subjected to the same processing as environmental samples (including sample splitting, filtration, preservation, transportation, and laboratory handling). Field-blank samples were collected in the field at a sampling site and analyzed for the same constituents as environmental samples collected at that same site in order to identify any contamination that may have occurred during sample collection and processing. Equipment blanks were collected to check for contamination introduced by the sampling equipment and were analyzed for the same analytical suite used for environmental samples (excepting dissolved gases) (U.S. Geological Survey, variously dated). A pair of sequential replicate samples were collected at a sampling site using the same sampling equipment and protocols with sampling equipment cleaned between collection of the two samples.

\section{Hydrogeology}

Gem County is on the northwest margin of the Snake River Plain, "an arcuate topographic and structural depression that extends across southern Idaho. G eology and hydrology of [the] eastern and western parts of the Snake River Plain are distinctly different; the west is predominantly sedimentary rocks, and the east is predominantly volcanic rocks” (Newton, 1991, p. G2).

\section{Geologic Setting}

The oldest rocks exposed in Gem Country are granitic rocks of the Idaho Batholith that were intruded into older Paleozoic sedimentary rocks during the Late Cretaceous (about 85-67 million years ago [Ma]). During the Miocene, these rocks were uplifted and eroded, followed by the eruption of Idavada rhyolitic rocks (about 17-8 Ma) and then Columbia River basaltic rocks (17-5.5 Ma) as the track of the Yellowstone hot spot extended into the area. Faulting associated with this volcanic activity led to the formation of the western Snake River Plain about 11 Ma. This was followed by the formation of the Chalk Hills lake on the down-dropped plain: the sediments and volcanics of the Chalk Hills Formation were then deposited until the lake drained in late Miocene time (about $6 \mathrm{Ma}$ ) (Wood and Clemens, 2002).
Subsequently, after a period of erosion, Lake Idaho was formed on the plain during the Pliocene (about 4.5 Ma). Lake Idaho began draining during the late Pliocene (about $2 \mathrm{Ma}$ ), and as lake levels fluctuated, a major river emerged from the mountains north of the plain and west of the Boise area, creating a large river delta where it flowed into the remnants of Lake Idaho (Wood, 2004). By the Pleistocene (1.6 Ma), the basin had filled with sand and gravel deposits as streams migrated over the lacustrine sediments of the former Lake Idaho (Wood and Clemens, 2002; Wood, 2004). Concurrently, about 2.2 Ma and continuing into the Pleistocene, basalts of the Snake River Group were erupted and the major rivers of the modern western Snake River Plain, including the Boise and Payette Rivers, began incising into the older lake deposits. About 14,000-15,000 years ago, Bonneville Lake in Utah released a catastrophic flood that flowed down the Snake River Plain and was temporarily dammed at Hells Canyon. The resultant slack water backed up into the Boise, Payette, and Weiser River valleys and deposited silt and sand to an altitude of about 2,430 ft (O'Connor, 1990; Lewis and others, 2012). Since the Pleistocene, rivers and streams have eroded and partially filled their valleys with unconsolidated sediment in response to tectonic activity and fluctuations in climate.

The Malde and Powers (1962) stratigraphic classification of the western Snake River Plain has served as the basis for subsequent refinement in publications by Whitehead (1992), Othberg (1994), and Lewis and others (2012) (table 2). The upper Idaho Group has been further subdivided into the Terteling Springs Formation and overlying Pierce Gulch Sand (Burnham and Wood,1992; Othberg, 1994; Wood and Clemmons, 2002; Wood, 2004). Because there has been no published description of these units in most of the study area, the term "Idaho Group" is used in the current report.

\section{Hydrogeologic Framework}

The geologic units that form aquifers in the study area can be combined into hydrogeologic units (HUs): "one or more geologic units which have similar hydrogeological characteristics and behavior" (Australian Bureau of Meteorology, 2016). The hydrogeologic units described in this report are based on the geologic-map units (GMUs) of the most recent geologic map of Idaho (Lewis and others, 2012) (fig. 2, table 2). Although this geologic map is small-scale and of the entire state (thus necessitating the combination and generalization of like geologic units) the resulting GMUs are sufficiently detailed for classification into HUs. This report defines three HUs in the study area: Quaternary-Tertiary deposits (QTd), Tertiary Idaho Group rocks (Tig), and Tertiary-Cretaceous igneous rocks (TKi) (table 2). Wells were assigned to one of the three HUs based on well construction and lithology taken from well-driller reports (see section, "Well-Driller Reports"). Thus, 13 wells were assigned to the QTd HU, 31 wells to the Tig HU, and 3 wells and 1 spring to the TKi HU (fig. 2). 


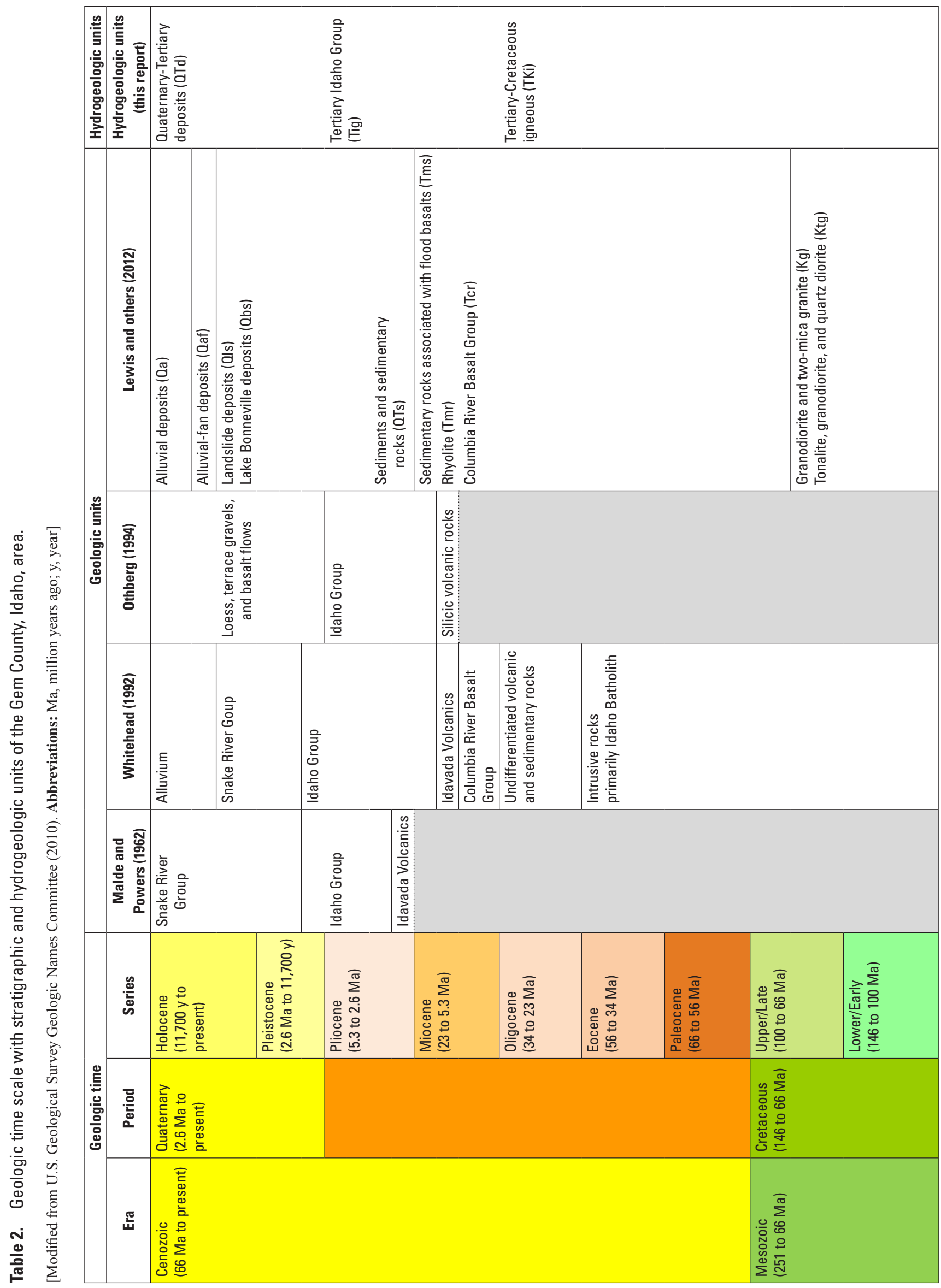




\section{Quaternary-Tertiary Deposits Hydrogeologic Unit (QTd)}

The Quaternary-Tertiary deposits HU is composed of five GMUs described by Lewis and others (2012): "Alluvial deposits” (Qa), "Alluvial-fan deposits” (Qaf), "Landslide deposits” (Qls), "Lake Bonneville deposits” (Qbs), and "Sediments and sedimentary rocks" of Quaternary to Tertiary age (QTs). Because the QTd is the uppermost HU and varies in thickness, wells may be screened across one or more of its component GMUs, or the underlying Tertiary Idaho Group HU (Tig).

The "Alluvial deposits" (Qa) GMU is composed of unconsolidated clay, silt, sand, and gravel deposited by the Payette River and tributaries such as Squaw Creek (figs. 1 and 2) (Lewis and others, 2012). Areally, this GMU comprises most of the QTd HU and is generally adjacent to the Payette River and smaller streams; it underlies the modern flood plains. In the Emmett Valley, the QTd HU was formed during several cycles of deposition and erosion caused by fluctuations in climate and possibly tectonic activity. Sediments of the Qa GMU are incised into the older GMUs in the study area.

The "Alluvial-fan deposits" (Qaf) GMU is of limited areal extent, and exposures are located west of Sweet on the eastern flank of Squaw Butte and south and east of Montour on the northern flank of Crown Point (figs. 1 and 2) (Lewis and others, 2012). Similarly "Quaternary landslide deposits" (Qls) outcrop in a small area west of Highway 52 and the Black Canyon Diversion Dam (figs. 1 and 2). Sediment size in both these GMUs range through clay, silt, sand, and gravel (Lewis and others, 2012).

Sediments of the "Lake Bonneville deposits" (Qbs) GMU in the study area are primarily sand and silt deposited in slackwater areas of the Bonneville flood. They underlie the south and west areas of the Emmett North Bench, a $10 \times 2$ mi terrace with a surface at about 2,400 ft altitude; a small remnant also outcrops near Little Freezeout Hill on the southern margin of the Emmett Valley (figs. 1 and 2) (Lewis and others, 2012). Many wells on the Emmett North Bench are completed partially or entirely in this GMU.

The "Sediments and sedimentary rocks" (QTs) GMU underlies the north and east areas of the Emmett North Bench and a small area near Little Freezeout Hill (fig. 2) (Lewis and others, 2012). The sediments of this GMU are primarily silt, sand, and gravel that originally were deposited along streams, alluvial fans, or lakes. They are likely at least partly equivalent to the Quaternary-Tertiary Tenmile Gravel, as defined by Othberg (1986) and younger deposits.

The QTd HU underlies nearly all of the developed and agricultural land in the study area as well as canals, streams, and the Payette River. This HU receives surface water and applied irrigation water and therefore is more susceptible to contamination than other HUs. It is a productive HU, and most wells in the study area are completed in it, either entirely or partially. Groundwater in this HU is under unconfined to confined conditions.

\section{Tertiary Idaho Group Hydrogeologic Unit (Tig)}

The Tertiary Idaho Group (Tig) HU is the most areally extensive in the study area and is composed entirely of the "Miocene sedimentary rocks associated with flood basalts" (Tms) GMU of Lewis and others (2012). This GMU includes a wide range of consolidated to weakly consolidated sedimentary rocks across Idaho. In the study area, these rocks are mostly of the Idaho Group based on the definition of Othberg and Stanford (1992), Whitehead (1992), and Bond and others (2011). Where present, the QTd HU overlies the Tig HU; in areas near igneous outcrops, the TKi HU may underlie the Tig HU. Many wells penetrate the overlying QTd HU and are completed either completely or partially in the Tig $\mathrm{HU}$; therefore, it is a important source of water to wells in the study area. Groundwater in this HU is under unconfined to confined conditions. Currently (2016), petroleum exploration and production in Payette County is occurring in the Tertiary basin-fill sediments of the Idaho Group to a depth of as much as 6,200 ft (Johnson and others, 2013).

The upland that forms the divide between the Boise and Payette Rivers (the Boise Valley-Payette Valley interfluve) is primarily composed of upper Idaho Group rocks. At least some of these rocks likely are also part of the Glenns Ferry Formation of Malde and Powers (1962) or its local equivalent. Savage (1961) mapped most of the upland north of the Emmett Valley as Idaho Formation; this area is included in the Tms GMU by Lewis and others (2012). Their Tms GMU includes the Payette Formation (that term is not used in the current report because of uncertainty regarding its definition and extent). Savage (1958) defined the Payette Formation as underlying Columbia River basalts, but noted the difficulty of differentiating it from Idaho Group rocks because of lithologic similarities. Malde and Powers (1962) did not differentiate the Payette Formation from other Miocene rocks.

It is not known to what degree groundwater in the Tig HU of the Emmett Valley is hydraulically connected to aquifers of the Boise Valley-Payette Valley interfluve or the Treasure Valley. The Payette River follows the Western Idaho Fault System in the Emmett area, and a fault exposed in a Highway 16 road cut on Freezeout Hill shows a downward displacement of about $60 \mathrm{ft}$ to the southwest (Gilbert and others, 1983; Phillips, 2007). To the south, a number of faults are related to western Snake River Plain basin-bounding faulting, including the West Boise-Eagle fault of Wood and others (1981). These faults may partition the Boise Valley-Payette Valley interfluve into a number of discrete aquifers (SPF Water Engineering, 2004). Hydrogeologic studies for residential development on the Boise Valley-Payette Valley interfluve south of the study area have defined several informally named aquifers, including the Willow Creek aquifer of SPF Water Engineering (2004) and the Pierce Gulch sand aquifer of Squires and others (2007). 


\section{Blue Clay}

"Blue clay" is often noted in driller report lithologic descriptions from the study area, and well drillers commonly use it as a marker horizon. Sediments of the QTd HU are lithologically similar to those of the Tig HU, and may be at least partially derived from the erosion of the Tig HU; therefore, the contact between the two may not be discernible. The presence of blue clay is not a consistent indicator of the contact between the Idaho Group and overlying sediment because it may either be absent or may occur stratigraphically lower in the Idaho Group; however, its occurrence usually indicates the presence of Idaho Group rocks. Lithologic logs included in Savage (1961) show blue clay as "blue shale." Wood and Anderson (1981) and Anderson and Wood (1981) assigned the blue clay to the middle Glenns Ferry Formation of the Idaho Group and noted its presence from Boise to the Parma area (fig. 1). Anderson and Wood (1981, p. 37) ascribed the dark color "to sulfide enrichment [that] may indicate deposition under a reducing environment," but allowed for the possibility of "secondary iron sulfide enrichment [that] could be caused by post depositional water migration." Savage (1961) and Deick and Ralston (1986) noted the presence of blue clay in Payette County. Squires and others (1992) believed these sediments to represent lacustrine deposits and noted that they thicken to the west in the Boise area. Burnham and Wood (1992) assigned the blue clay to the mudstone facies of their Terteling Springs Formation.

Anderson and Wood (1981) speculated that the blue clay acted as an impermeable or semipermeable layer separating upper cold-water unconfined aquifers from lower warm-water confined aquifers. Such a temperature difference between the HUs was not noted during sampling for the current study, possibly because of the recharge of warmer irrigation water during the preceding summer months. In the study area, some well-driller reports show evidence of a temperature difference between HUs (Dennis Owsley, Idaho Department of Water Resources, written commun., August 2, 2016). Because the blue clay is not uniformly present in well-driller reports from the study area, its presence is not a reliable indicator of confined conditions.

Analysis of well-driller reports for the current study suggests that, where present, the top of the blue clay is roughly $100 \mathrm{ft}$ lower in altitude beneath the Emmett Valley than in the surrounding uplands and generally slopes to the south and west. This is in broad agreement with a map of the western Snake River Plain showing the top of the Tertiary mudstone facies sloping to the southwest (Wood, 1997). It is unknown if the surface representing the top of the blue clay in the Emmett Valley was affected by a previous episode of erosion by the Payette River and (or) faulting.

\section{Tertiary-Cretaceous Igneous HU (TKi)}

The TKi HU is composed of five GMUs defined by Lewis and others (2012): "Rhyolite” (Tmr), “Columbia River
Basalt Group” (Tcr), “Challis intrusive rocks” (Tei), and two units of the Idaho batholith, "Granodiorite and two-mica granite" (Kg) and "Tonalite, granodiorite, and quartz diorite" (Ktg). Where present, basalts of the Tcr GMU are in direct contact with the underlying granitic rocks of the $\mathrm{Kg}$ and $\mathrm{Ktg}$ GMUs (Lewis and others, 2016).

In Gem County, the "Rhyolite" (Tmr) GMU of Lewis and others (2012) outcrops in several small areas of the eastern Boise Front south of Pearl (fig. 3). This rhyolite is contemporaneous with Idavada volcanism. These outcrops are erosional remnants of limited extent. Although a few wells seem to penetrate this rhyolite, it is not clear whether production is from it or the underlying basalt or granite.

The "Columbia River Basalt Group” (Tcr) GMU of Lewis and others (2012) outcrops in much of eastern Gem County; in the study area it forms Squaw Butte, both sides of the valley of Squaw Creek, and the eastern part of the Boise Front north and south of Pearl (figs. 1 and 2). Fitzgerald (1982) and Bond and others (2011) mapped it as Imanha Formation, of the lower Columbia River Basalt Group; however, recent geologic mapping by Lewis and others (2016) concluded that "most if not all of the Columbia River basalt flows in the central and western M ontour quadrangle are Steens Basalt." Numerous springs issue from the basalt on the slopes of Squaw Butte; these, along with a number of wells completed in basalt, are an important source of water for domestic supply.

The "Challis intrusive rocks" (Tei) GMU of Lewis and others (2012) outcrops in a small area northeast of Pearl. No wells seem to be completed in these rocks.

In the study area, granitic rocks of the Atlanta lobe of the Idaho batholith include two GMUs of Lewis and others (2012): the "Granodiorite and two-mica granite" (Kg) and "Tonalite, granodiorite, and quartz diorite” (Ktg) GMUs. These rocks outcrop in the mountainous areas near Pearl and northeast of Sweet (figs. 1 and 2). Some wells completed in the granitic GMUs seem to penetrate other overlying GMUs of the TKi HU. Few wells are completed in these rocks and most wells are of low yield ( $25 \mathrm{gal} / \mathrm{min}$ or less); however, they are the only source of groundwater in some areas.

\section{Groundwater Levels}

Water levels were measured in 30 wells between September 8 and November 18, 2015 (fig. 3, table 1). The altitude of measured water-levels range from about 2,271 ft in well T02 completed in the Tig HU near the Payette River in westernmost Gem County to about 2,629 ft in well T21 completed in the Tig HU north of Emmett (fig. 3, table 1). Contours of water levels for wells completed in the QTd and Tig HUs are shown on figure 3. Generally, the altitude of the potentiometric surface suggests that groundwater flow is toward the Emmett Valley and Payette River. Broad areas of the mapped potentiometric surface are above the land surface of the Emmett Valley, indicating artesian conditions. Measured water levels are similar to those shown in Parliman (1986), 


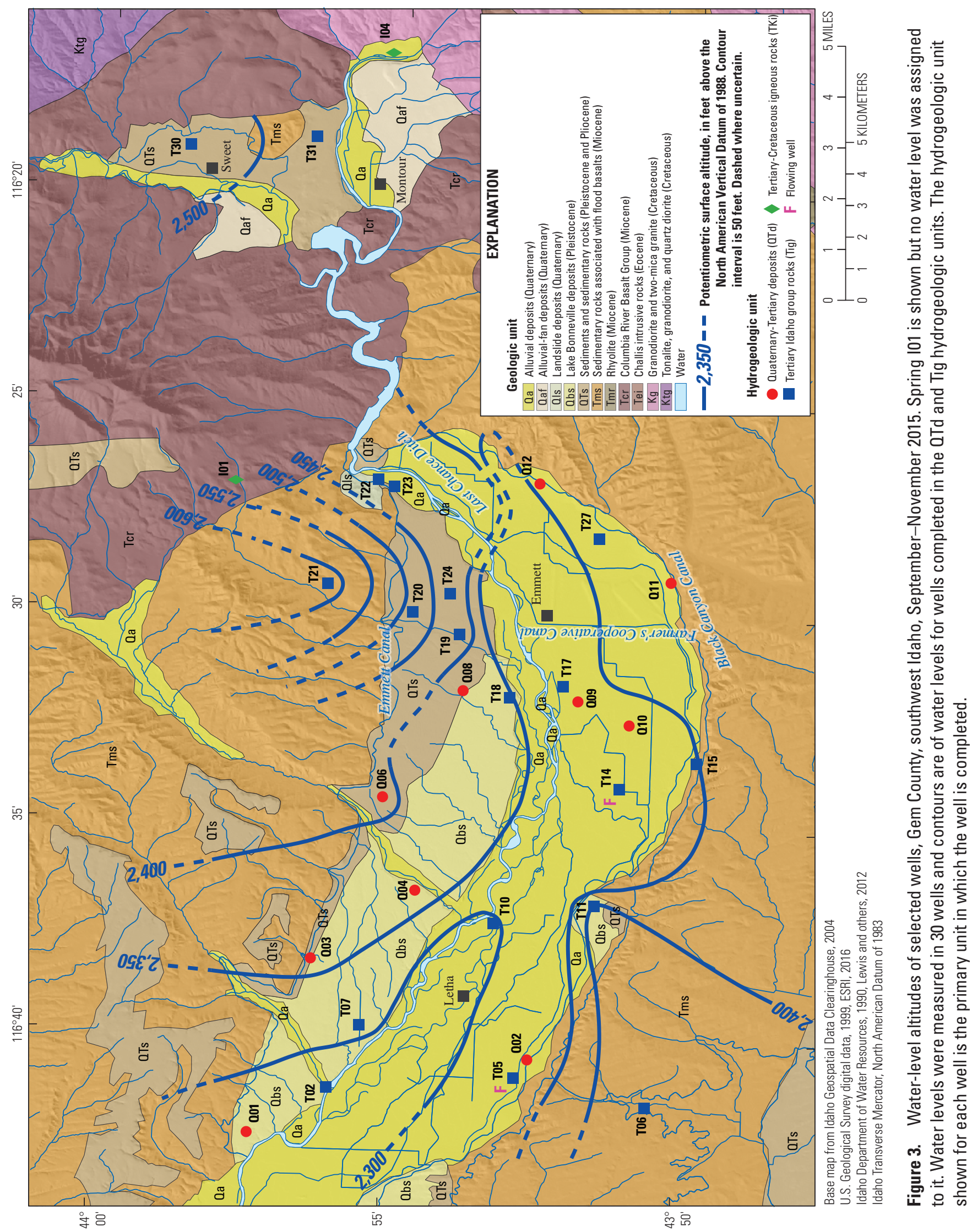


and water-level contours are generally in agreement with those shown in Lindholm and others (1988). Water levels from wells completed in the TKi HU were not contoured because they likely are not in hydraulic connection with the QTd and Tig HUs.

The altitude of the potentiometric surface shown in figure 3 should be considered an approximation for two reasons. Firstly, water levels were measured during water-quality sampling between September 8 and November 18, 2015; during this period irrigation and surface-water diversions had ended for the season. Longterm hydrographs from wells in the area indicate seasonal declines in water-levels in the QTd HU during this period; water levels in well 06N 01W 21CCC1 (not sampled for this study), measured twice monthly by IDWR during the sampling period, declined by about $0.6 \mathrm{ft}$ (Idaho Department of Water Resources, 2016b). Secondly, the altitude of the potentiometric surface is poorly constrained in areas with lowmeasurement density. A synoptic water-level measurement in a number of wells over a short period of time would help indicate whether the HUs are hydraulically connected and whether vertical hydraulic gradients are present: a three-well piezometer nest, 07N 03W 34ABD (not sampled for this study), shows a clear upward gradient (Idaho Department of Water Resources, 2016b).

\section{Ambient Water Quality}

\section{Water-Quality Conditions in 2015}

Analysis of 48 well and spring samples collected from September 8 to November 18, 2015, provides information on the ambient water-quality in groundwater over this 3-month period, and samples collected from the Payette River on November 19, 2015, reflect surface-water quality. Analytical results from this study, combined with historical water-quality measurements, provide insight into changes in water quality over time. Drinking-water guidelines presented in the tables and text of this report are the U.S. Environmental Protection Agency (EPA) National Primary Drinking Water Regulations (U.S. Environmental Protection Agency, 2012), of which the Maximum Contaminant Level (MCL) represents the highest level of a contaminant allowed in drinking water based on health standards. Also presented is a list of Secondary Maximum Contaminant Levels (SMCLs), which are aesthetic guidelines based on color and taste effects.

\section{Field Parameters}

Some properties of water are dependent on the environment from which the sample is taken and thus may change after the sample is collected and processed for analysis. For this reason, selected water-quality parameters are measured in the field during sampling and before significant changes can occur. These field parameters include water temperature, specific conductance, $\mathrm{pH}$, alkalinity, and dissolved oxygen (table A1). In groundwater, these parameters may vary between HUs reflecting differences in flow paths, sources of recharge, and whether the water is under confined or unconfined conditions.

Groundwater temperature ranged from 56.1 to $78.1^{\circ} \mathrm{F}$. When the Payette River was sampled on November 19, 2015, the water temperature at the upstream Emmett streamgage was $40^{\circ} \mathrm{F}$ and $42^{\circ} \mathrm{F}$ at the downstream Letha streamgage (fig. 1).

Specific conductance is a measure of the ability of water to conduct electrical current. Distilled water has a low specific conductance; conductance increases with the addition of dissolved ions. Specific conductance also varies with temperature; therefore, a constant temperature, typically $25^{\circ} \mathrm{C}$, is specified. Specific conductance ranges from about 1.0 microsiemens per centimeter $(\mu \mathrm{S} / \mathrm{cm})$ in distilled water to about $50,000 \mu \mathrm{S} / \mathrm{cm}$ in seawater and about 500,000 $\mu \mathrm{S} / \mathrm{cm}$ for naturally occurring brines (Hem, 1989). In the study area, specific conductance ranged from 80.0 to $695 \mu \mathrm{S} / \mathrm{cm}$ in groundwater samples and from 91.0 to $146 \mu \mathrm{S} / \mathrm{cm}$ in the two Payette River samples. The EPA has not set MCLs or SMCLs for specific conductance in potable water; however, the California Water Resources Control Board has recommended a SMCL of $900 \mu \mathrm{S} / \mathrm{cm}$ (California Water Resources Control Board, 2016).

The $\mathrm{pH}$ of water is a measure of the hydrogen ion activity and generally is used to describe whether water is acidic or basic. Most natural groundwater has a $\mathrm{pH}$ range from 6.5 to 8.5, but larger and smaller values can be found in some spring water (Hem, 1989). In groundwater sampled for this study, $\mathrm{pH}$ ranged from 6.3 to 9.4. The largest and smallest values of $\mathrm{pH}$ were in samples from the Tig HU. In some groundwater samples, the field and laboratory measurements varied by more than $1 \mathrm{pH}$ unit, likely due to changes in the sample temperature and pressure after sample collection. The two Payette River samples had $\mathrm{pH}$ values of 7.3 and 7.5.

The concentration of dissolved oxygen in water is a result of water temperature and pressure. In surface water, dissolved oxygen is an indicator of how well a stream is aerated, whereas in groundwater it is an indicator of a hydraulic connection to surface water and proximity to recharge locations, redox conditions (which affect solute mobility), and bacterial activity. Differences in dissolved-oxygen concentrations occurred in the three HUs (fig. 4A). Groundwater samples from the QTd HU ranged from 0.0 to $8.2 \mathrm{mg} / \mathrm{L}$, with a median concentration of $6.6 \mathrm{mg} / \mathrm{L}$. In the Tig $\mathrm{HU}$, sample concentrations ranged from 0.0 to $11.1 \mathrm{mg} / \mathrm{L}$, with a median concentration of $0.0 \mathrm{mg} / \mathrm{L}$ (many samples contained little or no dissolved oxygen). In the TKi HU, concentrations ranged from 0.0 to $7.9 \mathrm{mg} / \mathrm{L}$, with a median concentration of $2.4 \mathrm{mg} / \mathrm{L}$. Payette River samples had larger dissolved-oxygen concentrations (11.0 and $11.4 \mathrm{mg} / \mathrm{L}$ ), which are typical of surface water. 

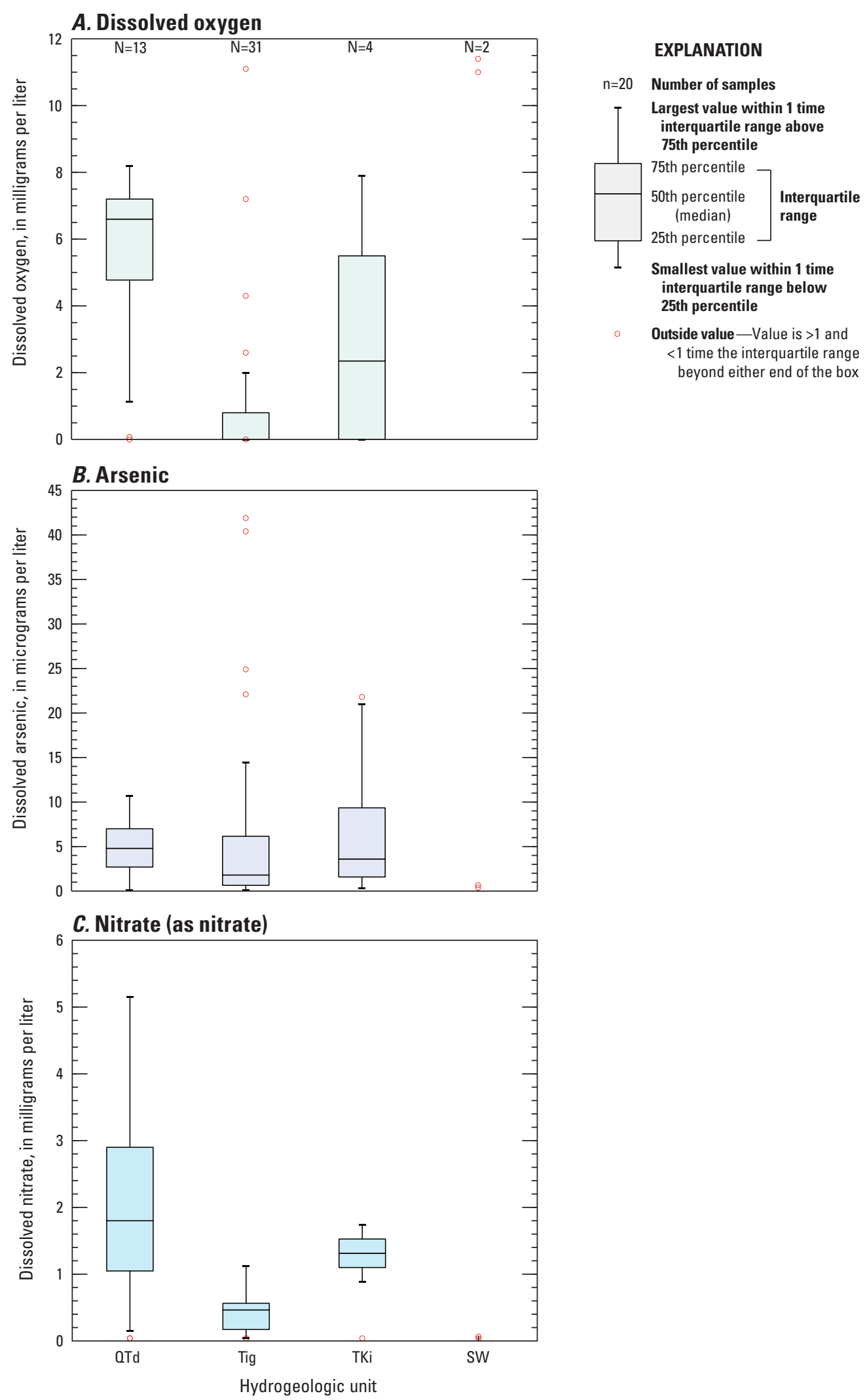

Figure 4. Distribution of dissolved oxygen, arsenic, and nitrate concentrations in groundwater and surface water, Gem County, southwestern Idaho, SeptemberNovember 2015. Hydrogeologic units: OTd, Quaternary-Tertiary deposits; Tig, Tertiary Idaho Group rocks; TKi, Tertiary-Cretaceous igneous rocks; SW, surface water. 
Because recharge water contains measurable concentrations of dissolved oxygen, groundwater samples with little or no measurable oxygen likely indicate microbial activity and (or) reducing conditions in an aquifer. Two possible mechanisms may be responsible for the small concentrations of dissolved oxygen in samples from the Tig unit. Either dissolved oxygen is reacting with reduced minerals in the blue clay layer, thus removing the dissolved oxygen from the water, or microbes are consuming dissolved oxygen as they break down organic material contained in the aquifer. When all of the dissolved oxygen has been consumed, other oxygenated compounds such as nitrate and sulfate may break down, ultimately resulting in the production of methane.

\section{Major lons}

Major ions are constituents typically detected in water at concentrations greater than $1.0 \mathrm{mg} / \mathrm{L}$ (U.S. Geological Survey, 2016c). Analytical results for major ions are shown in table A2. Of the major ions, only fluoride was detected at concentrations greater than EPA drinking-water standards. The EPA has set an MCL of $4.0 \mathrm{mg} / \mathrm{L}$ for fluoride because long-term exposure to fluoride over the MCL can cause bone disease or mottled teeth; there is also an SMCL of $2.0 \mathrm{mg} / \mathrm{L}$ (U.S. Environmental Protection Agency, 2012). Fluoride concentrations in samples collected from wells T24 and I04 were greater than the MCL, and the sample from well Q10 exceeded the SMCL of $2.0 \mathrm{mg} / \mathrm{L}$.

\section{Minor (or Trace) Elements}

Minor (or trace) elements are those typically detected in water at concentrations less than $1.0 \mathrm{mg} / \mathrm{L}$ (U.S. Geological Survey, 2016c). Analytical results for minor elements are shown in table A2. Of the minor element analyses in this study, only arsenic, iron, and manganese were detected at concentrations greater than EPA MCLs or SMCLs. The EPA has set an MCL of $10 \mu \mathrm{g} / \mathrm{L}$ for arsenic because long-term exposure to greater concentrations can cause skin damage or problems with the circulatory system (U.S. Environmental Protection Agency, 2012). Samples from six wells exceeded the EPA MCL; the largest concentration was $42 \mu \mathrm{g} / \mathrm{L}$ in a sample from the Tig HU (figs. 2 and 4B). Arsenic, like fluoride, is naturally occurring, and elevated concentrations are found throughout the Snake River Plain aquifer system and also in geothermal water (Wood and Low, 1988). Arsenic exists in several oxidation states, each of which is mobile under certain redox conditions. As a result, changes in the redox state of water due to pumping or induced recharge could affect arsenic concentrations in groundwater (Amirbahman and others, 2006).

Samples from eight wells, some in each of the three HUs, exceeded the EPA SMCL of $300 \mu \mathrm{g} / \mathrm{L}$ for iron. Large concentrations of iron may lead to discoloration or a metallic taste of water (U.S. Environmental Protection Agency, 2012).
The EPA SMCL of $50 \mu \mathrm{g} / \mathrm{L}$ for manganese was exceeded in 16 samples from all $3 \mathrm{HUs}$; concentrations above the SMCL may impart a black to brown color to water and (or) a bitter, metallic taste (U.S. Environmental Protection Agency, 2012).

\section{Radionuclides}

Uranium is a naturally occurring trace element that undergoes radioactive decay into different uranium isotopes, which then decay to isotopes of other elements such as radium and lead. Several types of radioactive particles are emitted as ionizing radiation during this natural decay process including alpha and beta particles. Samples were analyzed for uranium concentrations (in micrograms per liter) and radioactivity or alpha and beta particle activity (in picocuries per liter, pCi/L). Only one sample with a value of $18.1 \mathrm{pCi} / \mathrm{L}$ (T07) exceeded the $15 \mathrm{pCi} / \mathrm{L}$ MCL for alpha-particle activity (tables 3 and A2). Exposure to ionizing radiation above the MCL can potentially increase the risk of cancer (U.S. Environmental Protection Agency, 2012).

\section{Nutrients and Bacteria}

Nutrients such as nitrate, nitrite, orthophosphate, and ammonia can occur naturally, but high concentrations are more commonly associated with activities such as agriculture, wastewater discharge, and energy generation. As discussed in section, "Previous Work," in 2008 the IDEQ designated the Emmett North Bench as an NPA where more than 25 percent of the wells have nitrate (as nitrate) concentrations greater than $5 \mathrm{mg} / \mathrm{L}$. None of the samples collected for the current study exceeded the EPA MCL of $10 \mathrm{mg} / \mathrm{L}$ for nitrate in drinking water (tables 3 and A1), and only one sample (Q04) exceeded $5 \mathrm{mg} / \mathrm{L}$. Other nutrients, including nitrite, orthophosphate, and ammonia, were not detected in concentrations greater than the EPA drinking-water standards (table A1).

Samples from the QTd HU contained the largest range and concentrations of nitrate because the shallow alluvium is in direct hydraulic connection with surface water: concentrations ranged from less than 0.040 to $5.15 \mathrm{mg} / \mathrm{L}$, with a median concentration of $1.67 \mathrm{mg} / \mathrm{L}$ (fig. $4 \mathrm{C}$, tables 3 and A1). Nitrate concentrations in Tig HU samples ranged from less than 0.040 to $1.12 \mathrm{mg} / \mathrm{L}$, with a median concentration of $0.040 \mathrm{mg} / \mathrm{L}$, and nitrate concentrations in TKi HU samples ranged from less than 0.040 to $1.74 \mathrm{mg} / \mathrm{L}$ with a median concentration of $0.44 \mathrm{mg} / \mathrm{L}$ (fig. $4 \mathrm{C}$ ). The low concentrations of nitrate in the Tig HU may result from: (1) less direct hydraulic connection with surface water, (2) the presence of clays in the Tig HU (including blue clay) that act as barriers to vertical nutrient transport, and (or) (3) microbial denitrification, a process which is described further in section, "Field Parameters." Further evidence of denitrification in the Tig HU includes low concentrations of dissolved oxygen and the presence of ammonia. 
Table 3. Inorganic and nutrient material in groundwater collected from selected wells, Gem County, southwestern Idaho, 2015.

[U.S. Environmental Protection Agency (EPA) Maximum Contaminant Levels (MCLs) and EPA Secondary Maximum Contaminant Levels (SMCLs) are provided for reference. Hydrogeologic units: QTd, Quaternary-Tertiary deposits; Tig, Tertiary Idaho Group rocks; TKi, Tertiary-Cretaceous igneous rocks. Abbreviations: $\mu \mathrm{g} / \mathrm{L}$, microgram per liter; $\mathrm{mg} / \mathrm{L}$, milligram per liter; $\mathrm{pCi} / \mathrm{L}$, picocuries per liter; <, less than; -, not applicable]

\begin{tabular}{|c|c|c|c|c|c|c|c|}
\hline Analyte & \multicolumn{2}{|c|}{ EPA } & $\begin{array}{l}\text { Number of samples } \\
\text { with concentration } \\
\text { or activity greater } \\
\text { than EPA MCL }\end{array}$ & \multicolumn{3}{|c|}{ Detected concentration or activity } & $\begin{array}{l}\text { Hydrogeologic } \\
\text { units of wells } \\
\text { exceeding the } \\
\text { EPA MCL }\end{array}$ \\
\hline $\begin{array}{l}\text { Alpha radioactivity, filtered, } \\
\text { Th-230 curve (pCi/L) }\end{array}$ & 15 & - & 1 & 18.1 & 0.0 & 0.0 & Tig \\
\hline Aluminum, filtered $(\mu \mathrm{g} / \mathrm{L})$ & - & 200 & - & 54.9 & $<3.0$ & 4.0 & - \\
\hline Barium, filtered $(\mu \mathrm{g} / \mathrm{L})$ & 2,000 & - & 0 & 140 & 0.340 & 19.3 & - \\
\hline Beryllium, filtered $(\mu \mathrm{g} / \mathrm{L})$ & 4 & - & 0 & 0.12 & $<0.020$ & $<0.020$ & - \\
\hline Cadmium, filtered $(\mu \mathrm{g} / \mathrm{L})$ & 5 & - & 0 & 0.09 & $<0.030$ & $<0.030$ & - \\
\hline Chloride, filtered (mg/L) & - & 250 & - & 40.3 & 0.720 & 3.33 & - \\
\hline Chromium, filtered $(\mu \mathrm{g} / \mathrm{L})$ & 100 & - & 0 & 2.50 & $<0.30$ & $<0.30$ & - \\
\hline Manganese, filtered $(\mu \mathrm{g} / \mathrm{L})$ & - & 50 & - & 3,150 & $<0.40$ & 16.6 & - \\
\hline Nitrate, filtered (mg/L as nitrate) & 10 & - & 0 & 5.15 & $<0.040$ & - & - \\
\hline Nitrite, filtered (mg/L as nitrate) & 1 & - & 0 & 0.072 & $<0.001$ & $<0.001$ & - \\
\hline Selenium, filtered $(\mu \mathrm{g} / \mathrm{L})$ & 50 & - & 0 & 1.20 & $<0.05$ & $<0.05$ & - \\
\hline Silver, filtered $(\mu \mathrm{g} / \mathrm{L})$ & - & 100 & - & 0.048 & $<0.020$ & $<0.020$ & - \\
\hline Sulfate, filtered (mg/L) & - & 250 & - & 106 & 0.72 & 3.33 & - \\
\hline Thallium, filtered $(\mu \mathrm{g} / \mathrm{L})$ & 2 & - & 0 & $<0.030$ & $<0.030$ & $<0.030$ & - \\
\hline Uranium (natural), filtered $(\mu \mathrm{g} / \mathrm{L})$ & 30 & - & 0 & 22.0 & $<0.014$ & 0.24 & - \\
\hline Zinc, filtered $(\mu \mathrm{g} / \mathrm{L})$ & - & 5,000 & - & 271 & $<2.0$ & 2.2 & - \\
\hline
\end{tabular}

Bacteria in water, both total coliform and E. coli, indicate the possible presence of disease-causing organisms. The source of these bacteria is often human and animal waste transported by wastewater or agricultural runoff. The EPA MCL for total coliform bacteria is zero counts; any detection of coliform bacteria exceeds the MCL. Total coliform bacteria was detected in two groundwater samples from the QTd and Tig HUs (fig. 5, table A1); it is unclear how bacteria entered these two wells, but improper well completion, malfunctioning septic systems, or direct connection to surface water are common pathways. Both total coliform and E. coli are commonly detected in surface water, and both were detected in the two Payette River samples (fig. 5, table A1).

\section{Volatile Organic Compounds and Pesticides}

Samples were submitted for analysis of either selected volatile organic compounds (VOCs) or pesticides and their degradation products. Because water in the QTd HU is typically in better connection with surface water and directly underlies most of the developed and agricultural area of the Emmett Valley, most samples from this HU were analyzed for pesticides. Because VOCs are typically more mobile in groundwater than pesticides, samples from the Tig HU were analyzed primarily for VOCs. VOCs tend to volatilize when exposed to sunlight and aeration; thus, Payette River samples were analyzed only for pesticides. Two pesticide samples were broken during shipping to the laboratory.

VOCs are manmade and naturally occurring organic chemicals with low boiling points that cause them to volatilize to their gaseous form under most environmental conditions. VOCs include "components of gasoline, fuel oils, and lubricants, as well as organic solvents, fumigants, some inert ingredients in pesticides, and some by-products of chlorine disinfection" (U.S. Geological Survey, 2016b). Some VOCs are known carcinogens and may cause other health problems. Groundwater samples collected from 28 wells were analyzed for VOCs (table A3). Three different VOCs were detected in TKi and Tig HU samples from five wells: (1) toluene, a common industrial chemical and solvent; (2) tetrahydrofuran, a common solvent; and (3) carbon disulfide, which can have a natural source or may be manufactured for use as a solvent (fig. 5, tables 4 and A3). No VOC concentrations exceeded EPA MCLs (table 4). The source of these compounds are not known; improper well completion, malfunctioning septic systems, direct connection to surface water, or improper waste disposal are common pathways. 


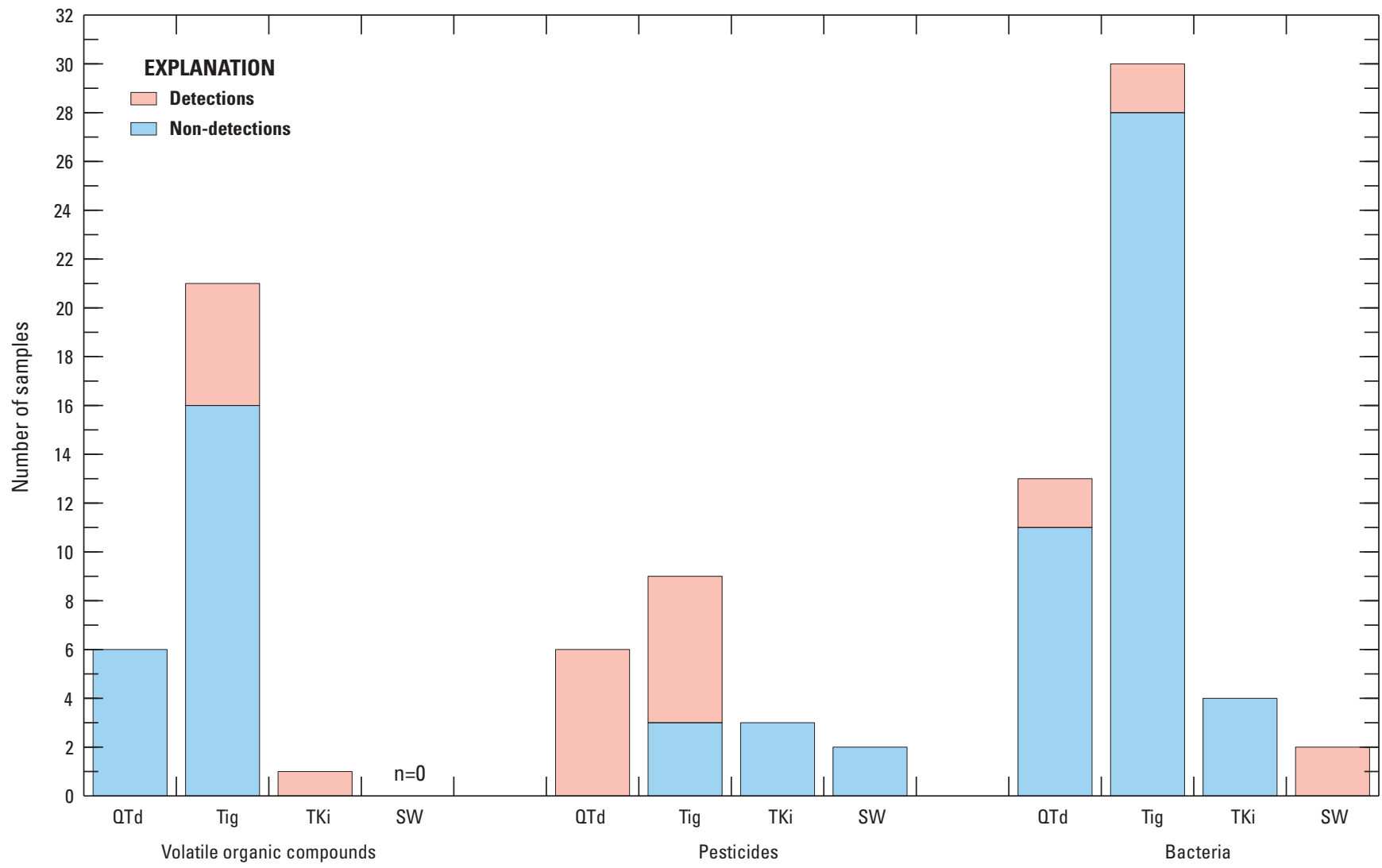

Analyte, by hydrogeologic unit

Figure 5. Volatile organic compounds, pesticides, and bacteria detections in groundwater and surface water, by hydrogeologic unit, Gem County, southwestern Idaho, September-November 2015. Hydrogeologic units: QTd, QuaternaryTertiary deposits; Tig, Tertiary Idaho Group rocks; TKi, Tertiary-Cretaceous igneous rocks; SW, surface water.

Table 4. Pesticides and volatile organic compounds detected in groundwater, Gem County, southwestern Idaho, 2015.

[E PA M CL: U.S. Environmental Protection Agency maximum contaminant level. M aximum detected concentration: E, estimated value; M, presence verified but not quantified. Hydrogeologic units: QTd, Quaternary-Tertiary deposits; Tig, Tertiary Idaho Group rocks; TKi, Tertiary-Cretaceous igneous rocks. Abbreviations: $\mu \mathrm{g} / \mathrm{L}$, microgram per liter; -, not applicable]

\begin{tabular}{|c|c|c|c|c|c|}
\hline Analyte & $\begin{array}{c}\text { Detection } \\
\text { limit } \\
(\mu \mathrm{g} / \mathrm{L})\end{array}$ & $\begin{array}{l}\text { EPA MCL } \\
(\mu \mathrm{g} / \mathrm{L})\end{array}$ & $\begin{array}{l}\text { Number of sites } \\
\text { with detections }\end{array}$ & $\begin{array}{l}\text { Maximum detected } \\
\text { concentration } \\
(\mu \mathrm{g} / \mathrm{L})\end{array}$ & $\begin{array}{l}\text { Hydrogeologic } \\
\text { units }\end{array}$ \\
\hline \multicolumn{6}{|l|}{ Volatile organic compounds } \\
\hline Toluene, unfiltered, recoverable & 0.03 & 1,000 & 1 & 1.1 & Tig \\
\hline Carbon disulfide, unfiltered & 0.1 & - & 2 & $\mathrm{M}$ & Tig \\
\hline Tetrahydrofuran, unfiltered, recoverable & 1.4 & - & 1 & 0.7 & TKi \\
\hline \multicolumn{6}{|l|}{ Pesticides } \\
\hline Simazine, filtered, recoverable & 0.006 & 4 & 1 & 0.007 & QTd \\
\hline Hexazinone, filtered, recoverable & 0.012 & - & 1 & 0.010 & QTd, Tig \\
\hline Prometon, filtered, recoverable & 0.010 & - & 2 & 0.02 & Tig \\
\hline Atrazine, filtered, recoverable & 0.008 & 3.0 & 4 & 0.009 & QTd, Tig \\
\hline $\begin{array}{l}\text { 2-Chloro-4-isopropylamino-6-amino-s- } \\
\text { triazine, filtered, recoverable }\end{array}$ & 0.006 & - & 4 & E 0.010 & QTd, Tig \\
\hline
\end{tabular}


Pesticides are manmade organic chemicals "applied to crops, rights of way, lawns, or residences to control weeds, insects, fungi, nematodes, rodents or other pests" (U.S. Geological Survey, 2016b). A total of 20 samples from groundwater and the Payette River were analyzed for pesticides and their degradation products (table A4). There were 12 detections of 5 pesticides or degradation products in QTd and Tig HU samples from 5 wells; some wells contained more than 1 compound (fig. 5, tables 4 and A4). The five pesticides are all members of the triazine class of herbicides or their degradation products: (1) simazine, (2) hexazinone, (3) prometon, (4) atrazine, and (5) deethylatrazine (2-chloro-4isorporylamino-6-amino-s-triazine), a degradation product of atrazine. No concentrations exceeded EPA MCLs (table 3).

The presence of pesticides in samples from both the Tig and QTd HUs indicate a similar source of recharge. Pesticides in groundwater are likely derived from irrigation water that, once applied, can recharge underlying aquifers. The presence of pesticides in both HUs suggests that irrigation water provides some component of recharge to both, although improper well completion or waste disposal can be factors. Pesticides also have been detected in previous groundwater studies in Gem County (Carlson and Atlakson, 2007).

\section{Oxygen-18 and Deuterium of Water}

Most chemical elements have one or more isotopes (atoms with the same number of electrons and protons but a different number of neutrons). Isotopes of the same element have slightly different chemical and physical properties but otherwise react similarly. The stable-isotope ratios of oxygen and hydrogen in natural water vary in response to precipitation source, altitude, season, temperature, amount of evaporation, and other factors. The ratios of oxygen-18 and hydrogen-2 (deuterium) to their lighter and more abundant isotopes, are expressed in delta $(\delta)$ notation and reported in per mil (\%o). This isotopic signature can help identify different sources of recharge to the HUs.

Craig (1961) developed a global meteoric water line (GMWL) to describe the relation between hydrogen and oxygen isotope ratios in natural terrestrial waters, expressed as a worldwide average. Because the isotopic signature of water varies by location, samples of local precipitation are used to develop a local meteoric water line (LMWL) for a specific area. The LMWL is used to describe variation in the isotopic signature of local precipitation and its deviation from the GMWL. Meteoric water lines are expressed by a general line equation with the form of:

$$
\delta^{2} \mathrm{H}=\mathrm{m} \times \delta^{18} \mathrm{O}+\mathrm{b}
$$

where
$\delta^{2} \mathrm{H} \quad$ is the delta value for deuterium in per mil,
$\mathrm{m}$ is the slope of the line, dimensionless,
$\delta^{18} \mathrm{O} \quad$ is the delta value for oxygen-18 in per mil, and
b is the intercept with the y axis, dimensionless.

Slope and y-intercept values for the Craig (1961)

GMWL, and the Schlegel and others (2009) and Tappa (2013)

LMWLs for the Boise area are shown in table 5.

Isotopic signatures of samples collected for this study and MWLs are shown in table A2 and figure 6; all groundwater samples plot below the GMWL and LMWLs. Water from the Tig HU contains isotopic signatures that are most depleted in $\delta^{18} \mathrm{O}$ (range of -17.9 to $-15.0 \%$ ), with TKi HU water having the next lowest $\delta^{18} \mathrm{O}$ values (-16.6 to $-15.2 \%$ ). These $\delta^{18} \mathrm{O}$ depleted signatures suggest that groundwater recharge occurs over a range of locations and seasons. Water in the QTd HU had isotopic signatures with $\delta^{18} \mathrm{O}$ values ranging from -16.5 to $-14.7 \%$; $\delta^{18} \mathrm{O}$ values for Payette River water was near the midpoint of this range (-15.4\%o for both samples).

The isotopic signatures for samples from the QTd HU (and to some extent, the Tig HU) likely reflect recharge from modern precipitation and infiltration of surface water through irrigation. Further evidence for this conclusion is the presence of pesticides and larger concentrations of nitrate in samples from both groups. The more depleted isotopic signatures observed in Tig HU samples T04, T05, and T21 may indicate an additional recharge source, precipitation at higher elevations, or cooler-season precipitation. The isotopic signatures of most samples collected for this study plot close to and below the LMWL (fig. 6); the Tig and TKi HU samples that plot farther below the line and to the right, such as I04, and T31, may have been affected by water-rock interaction suggesting longer residence times or geothermal influence. Two of these samples, T09 and T24, also have the largest concentrations of methane, suggesting that they may have been altered by geological and (or) microbial processes.

Table 5. Slope and y-intercept values for meteoric water line equations used in this report.

[Meteoric water lines are expressed by a general line equation (see eq. 1)]

\begin{tabular}{llcl}
\hline \multicolumn{1}{c}{$\begin{array}{c}\text { Meteoric } \\
\text { water line }\end{array}$} & $\begin{array}{c}\text { Slope } \\
(\boldsymbol{m})\end{array}$ & $\begin{array}{c}\text { Y-intercept } \\
(\boldsymbol{b})\end{array}$ & \multicolumn{1}{c}{ Reference } \\
\hline Global & 8 & 10 & Craig (1961) \\
Local, Boise area & 6.94 & -10.7 & Schlegel and others (2009) \\
Local, Boise area & 7.4 & -2.17 & Tappa (2013) \\
\hline
\end{tabular}




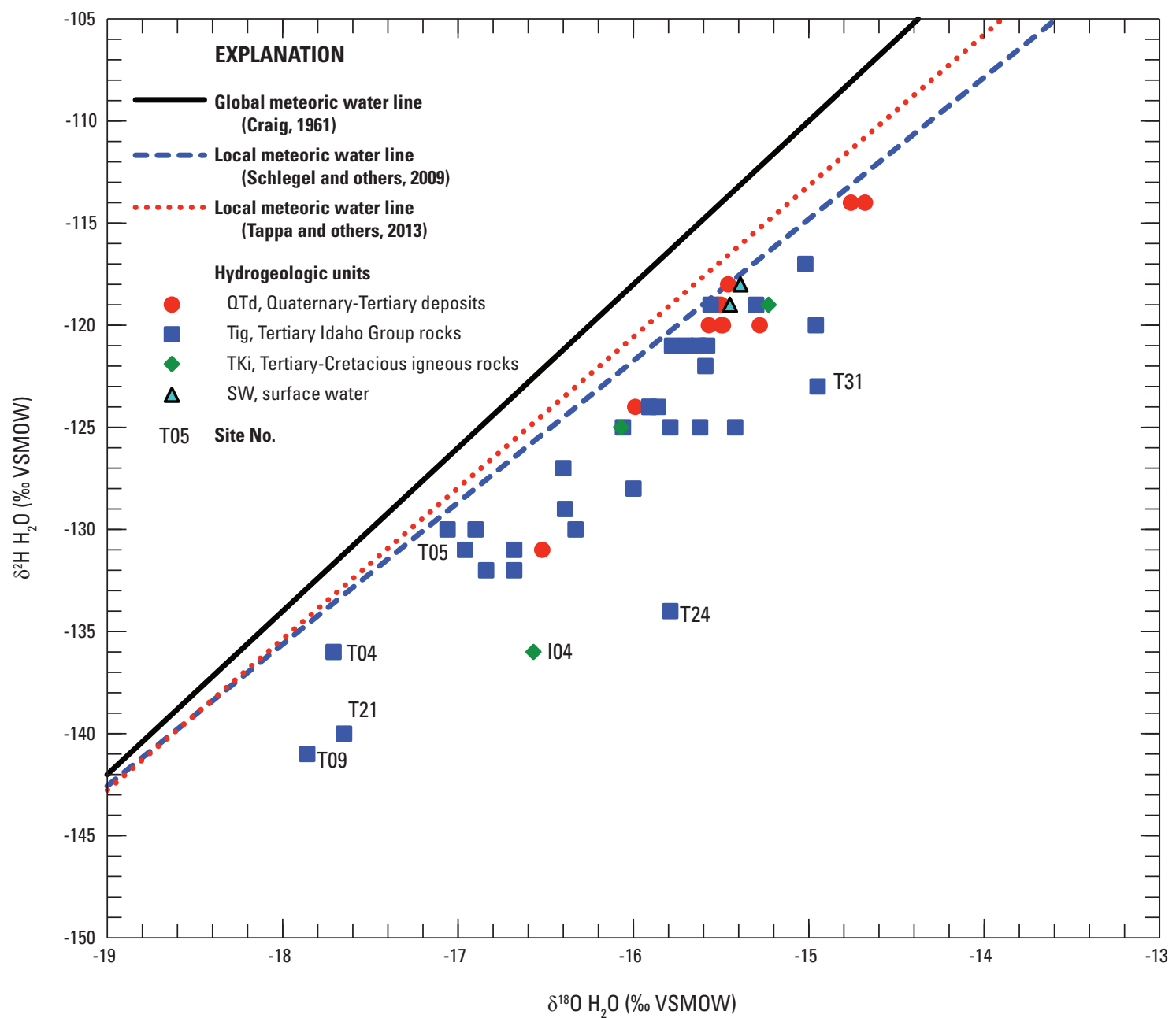

Figure 6. Stable isotopes of oxygen and hydrogen in groundwater and surface water samples, Gem County, southwestern Idaho, September-November 2015. $\delta^{2} \mathrm{H}$, delta value for deuterium; $\delta^{18} 0$, delta value for oxygen-18; \%o, per mil; VSMOW, Vienna Standard Mean Ocean Water.

\section{Dissolved Gases}

Methane $\left(\mathrm{CH}_{4}\right)$ and higher-chain hydrocarbons, such as ethane $\left(\mathrm{C}_{2} \mathrm{H}_{6}\right)$, propane $\left(\mathrm{C}_{3} \mathrm{H}_{8}\right)$, and butane $\left(\mathrm{C}_{4} \mathrm{H}_{10}\right)$, can occur naturally in groundwater either from in-situ microbial action or upward migration from underlying hydrologic units. All groundwater samples (but no Payette River samples) collected for this study were analyzed for these hydrocarbons and dissolved gases of hydrogen, argon, oxygen, carbon dioxide, dinitrogen, carbon monoxide, propene, and carbon compounds (table A5). Methane was detected in 36 samples and 6 samples contained sufficient concentrations for analysis of the carbon $\left({ }^{13} \mathrm{C} /{ }^{12} \mathrm{C}\right)$ and hydrogen isotope ratios $\left({ }^{2} \mathrm{H} /{ }^{1} \mathrm{H}\right)$. Dissolved methane was detected in samples from all three HUs (tables 6 and A5), with the largest concentrations detected in Tig HU samples.

Methane was detected in 26 of the 31 samples collected from Tig HU wells; 7 of the 13 samples collected from QTd wells; and 3 of the 4 samples collected from TKi HU wells and springs (tables 6 and A5). All methane concentrations from the TKi HU were less than $0.5 \mathrm{mg} / \mathrm{L}$. The three wells with the largest methane concentrations (Q10, T09, and T24) also contained ethane at less than $0.0006 \mathrm{mg} / \mathrm{L}$. As with methane, ethane may be produced by microbial activity (Henrichs and others, 2006) or thermogenic processes. Neither propane or butane were detected in the samples from Gem County. 
Because methane is flammable and can degas as groundwater is pumped and passed through plumbing, the U.S. Office of Surface Mining has recommended action levels for dissolved methane in water (Eltschlager and others, 2001). Concentrations of dissolved methane greater than $28 \mathrm{mg} / \mathrm{L}$ indicate "that potentially explosive or flammable quantities of the gas are being liberated in the well and/ or ... in areas of the home" and for concentrations between 10 and $28 \mathrm{mg} / \mathrm{L}$ "remediation may be prudent to reduce the methane concentration to less than $10 \mathrm{mg} / \mathrm{L}$... [and] ... that ignition sources [should] be removed from the immediate area” (Eltschlager and others, 2001, p. 40). The approximate solubility limit of methane in freshwater at atmospheric pressure is $28 \mathrm{mg} / \mathrm{L}$. Thus, the largest concentration of methane measured for the current study, $40 \mathrm{mg} / \mathrm{L}$ in a sample from well T24, is considered to be an explosion hazard by the U.S. Office of Surface Mining.

Isotopic analysis of the methane samples indicates that gas could be generated by either biological or thermogenic processes. The carbon-13 to carbon-12 values of methane (expressed as $\delta^{13}$ ) ranged from -65.95 to $-39.71 \%$, and $\delta^{2} \mathrm{H}$ values of methane ranged from -290.6 to -203.4\% (table A5). The isotopic signatures of the six samples analyzed for this study, and the probable fields of methane sources are shown in figure 7. These fields were developed for Paleozoic rocks associated with the Marcellus Shale (Whiticar, 1999; Sharma and others, 2014) and the isotopic signatures of methane collected for this study indicate that sources may be thermogenic, microbial, or a mixture of the two (Whiticar, 1999; Sharma and others, 2014).

Several lines of evidence suggest that some of the natural gas in Gem County is of biogenic origin. Dissolved methane levels in groundwater are related to redox-sensitive parameters; samples with detectable methane contained no detectable dissolved oxygen and low levels of nitrate and sulfate, indicating that the methane may have been produced by microbial activity. Furthermore, comparisons of the relation of $\delta^{2} \mathrm{H}$ in methane to $\delta^{2} \mathrm{H}$ water and the molecular ratio of methane and ethane to $\delta^{13} \mathrm{C}$ in methane suggest a biogenic source of methane for the samples (Sharma and others, 2014). Microbial gas generation is controlled by the amount and bioavailability of organic carbon and the absence of alternate electron acceptors, such as oxygen, iron, nitrate, and sulfate, which may cause other microbial communities to outcompete methanogens for organic substrates. The lack of propane and other higher-chain hydrocarbons in dissolved-gas samples suggests that methane in the groundwater of the study area is at least partially microbial in origin.

Other evidence suggests that some of the natural gas in Gem County is of thermogenic origin. Thermogenic methane may have formed at depth and then migrated upward into the aquifer. Thermogenic gas is produced by the thermal decomposition (cracking) of longer-chain hydrocarbon kerogen or oil at high burial temperatures. Thermogenic
Table 6. Dissolved methane concentrations in groundwater by hydrogeologic unit, Gem County, Idaho, 2015.

[Hydrogeologic unit: QTd, Quaternary-Tertiary sand and gravel; Tig, Tertiary Idaho Group; TKi, Tertiary-Cretaceous igneous rocks. A bbreviations: $\mathrm{mg} / \mathrm{L}$, microgram per liter. ND, not detected; <, less than; $>$, greater than]

\begin{tabular}{lccc}
\hline \multirow{2}{*}{$\begin{array}{c}\text { Methane } \\
\text { concentration } \\
\text { (mg/L) }\end{array}$} & \multicolumn{2}{c}{ Number of samples by hydrogeologic unit } \\
\cline { 2 - 4 } & Otd & Tig & TKi \\
\hline ND & 6 & 5 & 1 \\
$<0.5$ & 6 & 22 & 3 \\
$0.5-1.0$ & - & 2 & - \\
$1.01-10.0$ & 1 & 1 & - \\
$10.01-28.0$ & - & - & - \\
$>28$ & - & 1 & - \\
\hline Total & 13 & 31 & 4 \\
\hline
\end{tabular}

methane formation is feasible at temperatures of $315-428^{\circ} \mathrm{F}$, whereas microbially produced (biogenic) methane typically is produced at temperatures less than $122^{\circ} \mathrm{F}$ (Stolper and others, 2014). The presence of geothermal water in the study area with temperatures as high as $268^{\circ} \mathrm{F}$ (discussed in section, "Water Resources") coupled with high heat-flow values on the northern margin of the western Snake River Plain (Brott and others, 1976) suggest that methane in the study area could have a thermogenic source. Another line of evidence is the presence of ethane in three samples because ethane is typically produced in conjunction with thermogenic methane; although the lack of higher chain gasses such as propane and butane suggest a lower degree of thermal maturity.

The isotopic signatures shown in figure 7 and the lines of evidence presented in this section suggest that the methane in the study area is of both biogenic and thermogenic origin. Because processes such as oxidation of thermogenic gas, migration, mixing, groundwater recharge, and structural and thermal history may alter the isotopic signature of methane, definitive source characterization may be difficult, or at least require further sampling and analysis (James, 1983; Flores and others, 2008).

\section{Quality Assurance and Quality Control}

No evidence of contamination was found in the one equipment blank, one source solution blank, five field blanks, or three replicate samples collected during the study. Most of the analytes in the replicate samples were within 10 percent relative percent difference (RPD) of each other; however, in one sample replicate, the RPD for copper, lead, and zinc between replicates was greater than 10 percent. Because the measured concentrations of these analytes were small, slight differences in concentrations produced RPDs of 10 percent. 


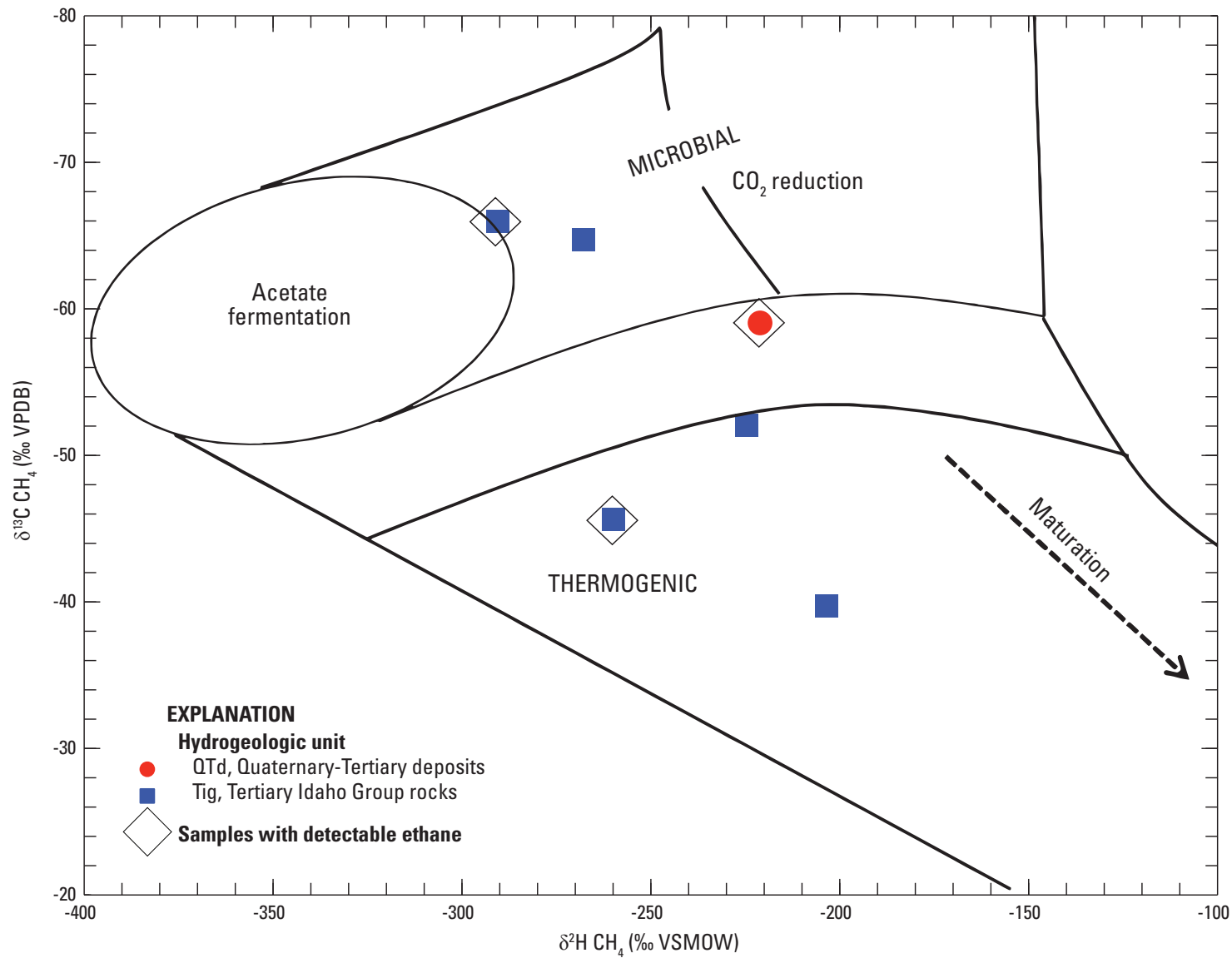

After Whiticar (1999) and Sharma and others (2014)

Figure 7. Stable isotopes of methane in groundwater collected from six wells, southwestern Gem County, Idaho, September-November 2015. $\delta^{2} \mathrm{H}$, delta value for deuterium; $\mathrm{CH}_{4^{\prime}}$ methane; $\delta^{13} \mathrm{C}$, delta value for carbon-13; $\%$, per mil; VSMOW, Vienna Standard Mean Ocean Water; VPDB, Vienna Pee Dee Belemnite; $\mathrm{CO}_{2}$, carbon dioxide.

\section{Trends}

Fifteen of the wells sampled for the current study had been sampled previously, thus allowing evaluation of possible water-quality trends over time. Historical samples have been collected by the USGS, IDEQ, IDWR, and ISDA (no ISDA samples were used in this analysis because of uncertainty in well-identification) (table A6). Sampling objectives may have varied between the sampling events, so only analytes included in the current study and sampled five or more times previously are reported and examined for trends.

No sites have sufficient data for a robust statistical analysis; therefore, only concentrations of nitrate and arsenic were plotted and visually examined for monotonic trends over time (fig. 8). Nitrate concentrations for nine wells are shown in figure $8 \mathrm{~A}$; no concentrations varied by more than $0.4 \mathrm{mg} / \mathrm{L}$ over the sampling period, and most varied by less than $0.2 \mathrm{mg} / \mathrm{L}$. Arsenic concentrations for eight wells are shown in figure $8 \mathrm{~B}$. The concentration of arsenic in well T23 varied by nearly $20 \mu \mathrm{g} / \mathrm{L}$, but by less than $10 \mu \mathrm{g} / \mathrm{L}$ in the rest of the wells. The relatively stable concentrations in a given well for most constituents over time are notable in that samples were collected by multiple agencies and analyzed by multiple laboratories, which suggests that results are comparable between agencies over time. 

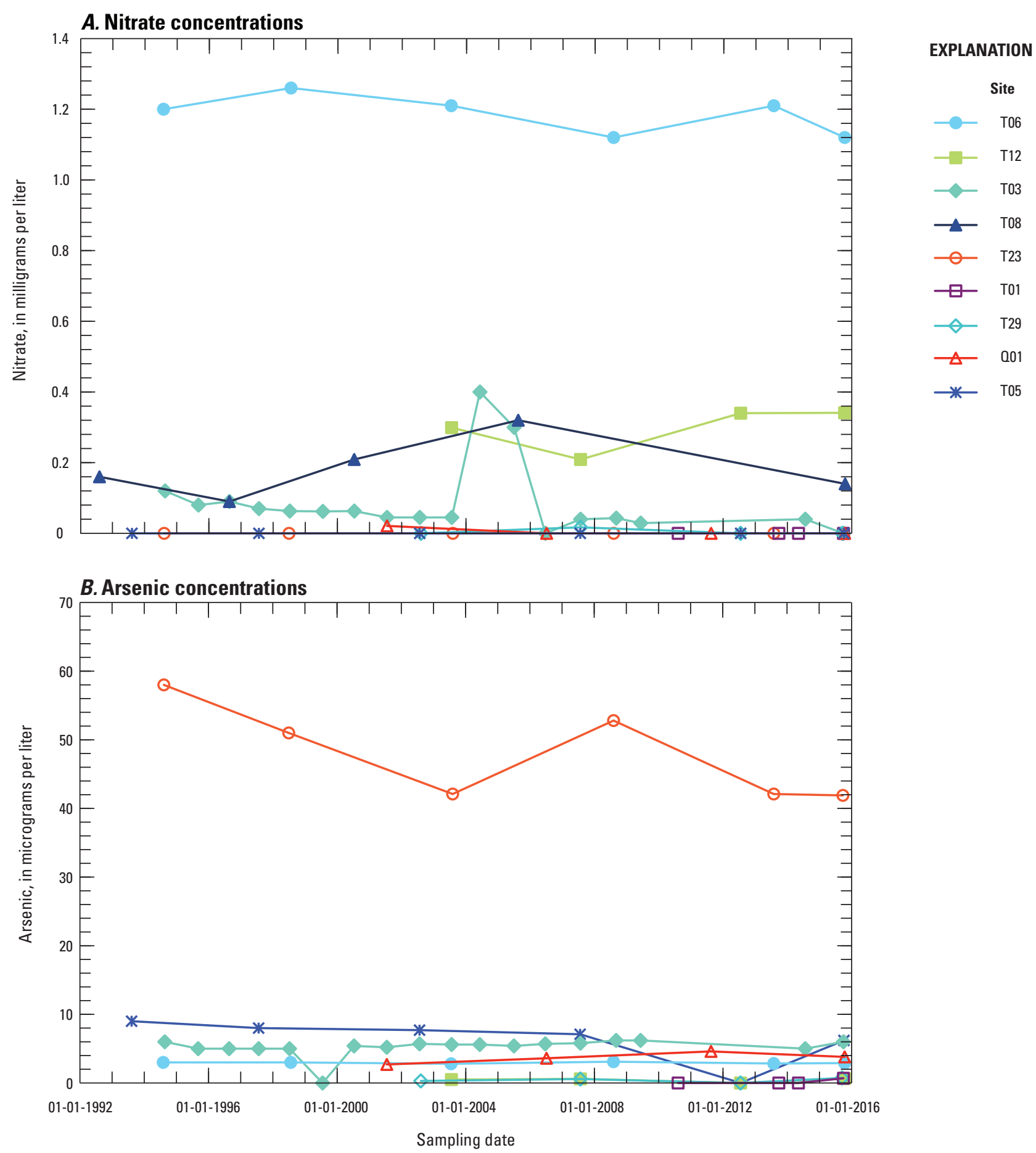

Figure 8. Nitrate and arsenic concentrations in groundwater in selected wells, Gem County, southwestern Idaho, 1992-2015. 


\section{Additional Needs for Groundwater- Quality Monitoring}

Samples collected over a relatively short period of time, such as for the current report, provide an instantaneous "snapshot" of groundwater quality, but they do not describe water-quality changes and (or) trends over time. For this reason, monitoring networks are created to identify these changes and (or) trends. Ongoing monitoring is necessarily a balance between the objectives and scope of the monitoring program and available funding. The Advisory Committee on Water Information recognizes three main categories of monitoring networks; in Gem County the trend monitoring and special-studies monitoring categories are applicable (Advisory Committee on Water Information, 2013).

Trend monitoring is designed to look at long-term patterns in water quality over time. In this category of network, a subset of wells are sampled repeatedly over time in order to develop time series of constituent concentrations to evaluate any changes in groundwater quality. Sampling frequency is dependent on the trend of interest, so trend monitoring can vary from multiple samples in a season to single samples in years or decades. Common sampling frequencies for wells in newly established monitoring networks are annually for a period of 3-5 years until data are sufficient to evaluate baseline conditions (Advisory Committee on Water Information, 2013).

Special-studies monitoring typically addresses specific questions about water-quality conditions and are most often associated with evaluating groundwater resources at risk, or potential risk, from water-quality impairment. In this category of monitoring, wells are sampled for a specific purpose such as the observation of the effects of a particular activity. Sampling frequency varies and depends on the nature of the study. Sampling may include core constituents as well as the specific constituents of concern (Advisory Committee on Water Information, 2013).

A possible approach to water-quality monitoring in Gem County would be continued sampling for selected constituents at a subset of wells on a 3-5 year interval for trend monitoring. Sampling of this smaller network could be staggered to spread costs over multiple years. If land-use changes occur in a specific area special-studies monitoring could be implemented for constituents of concern. Because previous sampling has identified their occurrence at or above relevant standards selected major ions, trace elements, nutrients, and bacteria analyses are appropriate for ongoing monitoring. VOCs were detected during the current and previous studies and often are indicative of changes in land use. Although pesticides have been detected previously, their widespread use in the county reduces their utility as indicators of water-quality changes due to changes in land use. Other areas of the country with active natural gas-extraction have shown increased methane concentrations in water (Osborn and others, 2011). Thus, if petroleum production occurs in Gem County, special-studies monitoring for methane and other dissolved gases could indicate changes in water quality.

Currently (2016) several monitoring networks are active in Gem County. The IDWR Statewide Ambient Ground Water Quality Monitoring Program samples wells in its network on a rotating basis every 5 years (Idaho Department of Water Resources, 2016c). The IDEQ samples wells in the Emmett North Bench NPA for a limited number of constituents about every 5 years. The IDEQ also assists public water systems with water-quality monitoring required by the Federal Safe Drinking Water Act. Sampling frequency for this latter program varies by the type of well and constituent, but because this monitoring is intended to characterize drinking water as actually consumed, water may travel some distance through plumbing before reaching the sampling point and thus may not accurately reflect groundwater quality (Idaho Department of Environmental Quality, 2016). Some wells sampled for the current study are also sampled as part of one or more of these three networks. Future water-quality sampling in Gem County should be coordinated with sampling of these other networks to avoid duplication of effort and possibly reduce monitoring costs. Data from ongoing monitoring should be examined periodically for developing trends or changes that require adjustment to the monitoring plan.

\section{Summary and Conclusions}

In recent years, the rapid population growth in Gem County, Idaho, has been similar to other counties in southwestern Idaho, increasing about 54 percent from 1990 to 2015. The entire population of the study area depends on groundwater for domestic supply, either from self-supplied domestic, community, or municipal-supply wells. This population growth and changes in land use, including potential petroleum exploration and development, has concerned the public and local officials and indicated the need for a water-quality assessment of groundwater used for human consumption. To this end, the U.S. Geological Survey, in cooperation with Gem County and the Idaho Department of Environmental Quality, assessed the water-quality of groundwater from freshwater aquifers used for domestic supply in Gem County. A total of 47 wells, 1 spring, and 2 surface-water sites on the Payette River were sampled September 8-November 19, 2015, for a wide variety of constituents. Analytes included major ions, trace elements, nutrients, bacteria, radionuclides, dissolved gasses, stable isotopes of water and methane, and either VOCs or pesticides.

In order to place analytical results in context, a conceptual hydrogeologic framework was developed in which three hydrogeologic units (HUs) were described: Quaternary-Tertiary deposits (QTd), Tertiary Idaho Group 
rocks (Tig), and Tertiary-Cretaceous igneous rocks (TKi). The QTd and Tig HUs are significant sources of groundwater supply in the study area.

The QTd HU underlies nearly all of the developed and agricultural land in the study area, as well as canals, streams, and the Payette River. This HU is more susceptible to contamination than other HUs because it is in direct contact with surface water and applied irrigation water that reaches the water table. It is primarily composed of unconsolidated sediment, and most of wells in the study area are completed either or partially completed in this HU. In nearly all areas it is directly underlain by the Tig HU.

Most of the study area is underlain by the Tig HU either on the surface or beneath the QTd HU, which is composed of consolidated to weakly consolidated sedimentary rocks. The Tig HU is a significant source of water to wells in the study area because many wells penetrate the overlying QTd HU and are completed either partially or entirely in the Tig HU.

The TKi HU is composed of consolidated igneous rocks including rhyolite, basalt, and granitic rocks. Most of the eastern part of the study area is underlain by this HU. Although basalts can yield significant quantities of water to wells and springs, wells completed in granitic rocks tend to have low yields.

Water levels were measured in 30 wells during sampling, and a groundwater-level altitude map was constructed. This map was completed with the assumption that the QTd and Tig HUs are in good hydraulic connection. The map shows groundwater flow toward the Emmett Valley and Payette River.

Analytical results from 48 groundwater samples indicate that groundwater in Gem County is generally of good quality. Two wells contained water with fluoride concentrations greater than the MCL of 4 milligrams per liter (mg/L), and a third groundwater sample exceeded the U.S. Environmental Protection Agency (EPA) SMCL of $2 \mathrm{mg} / \mathrm{L}$. Samples from six wells contained arsenic at concentrations greater than the EPA MCL of 10 micrograms per liter $(\mu \mathrm{g} / \mathrm{L})$; the maximum arsenic concentration was $42 \mu \mathrm{g} / \mathrm{L}$. A sample collected from one well exceeded the EPA MCL of $15 \mathrm{pCi} / \mathrm{L}$ for alpha particle activity. Although previous sampling has detected groundwater with nitrate concentrations greater than the MCL of $10 \mathrm{mg} / \mathrm{L}$ in some areas of Gem County, only one sample exceeded the IDEQ threshold of $5 \mathrm{mg} / \mathrm{L}$ with a concentration of $5.2 \mathrm{mg} / \mathrm{L}$. Coliform bacteria was detected in four groundwater samples and both total coliform and Escherichia coli were detected in the two Payette River samples.

Stable isotopes of oxygen-18 and hydrogen-2 (deuterium) in water suggest sources of recharge to the three HUs. The isotopic signatures for samples from the QTd HU (and to some extent, the Tig HU) likely reflect recharge from modern precipitation and infiltration of surface water through irrigation. The more negative isotopic signatures observed in Tig HU samples may indicate an additional recharge source, from higher elevations, or from cooler-season precipitation.
Three volatile organic compounds were detected in samples from five wells: toluene, a common industrial chemical and solvent; tetrahydrofuran, a common solvent; and carbon disulfide, which can have a natural source or may be manufactured for use as a solvent. Five pesticides of the triazine class of herbicides were detected in samples from five wells; all concentrations were small, and none were greater than applicable EPA MCLs. Methane was detected in samples from 36 wells, and concentrations in 1 well were large enough to be considered an explosion hazard based on guidelines established by the U.S. Office of Surface Mining. Stable isotope compositions of methane in six samples suggest that methane in Gem County groundwater is probably of thermogenic and biogenic origin.

\section{Acknowledgments}

Ed Hagan of the Idaho Department of Environmental Quality, Dennis Owsley of the Idaho Department of Water Resources, and G.M. Clark and T.M. Kresse of the U.S. Geological Survey (USGS) provided technical information, discussion, and suggestions during the preparation of this report. Technical and field assistance was provided by M.L. Williams, Crystal Sverdsten, and R.J. Weakland of the USGS. Assistance with landowner contacts and permissions was provided by Robert and Donna Hawthorne and Gem County Commissioner Mark Rekow. Special thanks goes to the landowners who gave permission to sample their wells, in several instances at some inconvenience to themselves. Finally, thanks to the citizens of Gem County who helped fund and support this work.

\section{References Cited}

Advisory Committee on Water Information, 2013, A national framework for ground-water monitoring in the United States: U.S. Department of the Interior, Water Information Coordination Program, Subcommittee on Ground Water, 168 p., accessed November 7, 2016, at http://acwi.gov/sogw/ ngwmn_framework_report_july2013.pdf.

Amirbahman, A., Kent, D.B., Curtis, G.P., and Davis, J.A., 2006, Kinetics of sorption and abiotic oxidation of arsenic(III) by aquifer materials: Geochimica et Cosmochimica Acta, v. 70, no. 3, p. 533-547, doi:10.1016/j. gca.2005.10.036. 
Anderson, J.E., and Wood, S.H., 1981, Geohydrology, chap. 3 in Mitchel, J.C., ed., Geothermal investigations in Idaho-Part 11, Geological, hydrological, geochemical and geophysical investigations of the Nampa-Caldwell and adjacent area, southwestern Idaho: Boise, Idaho Department of Water Resources Water Information Bulletin No. 30, p. 33-42, accessed November 7, 2016, at http://www.idwr.idaho.gov/ files/publications/wib30p11-geothermal-nampa-caldwellareas.pdf.

Atlakson, Jessica, 2006, Payette and Gem Counties pesticide detections and Idaho’s Pesticide Management Plan: Boise, Idaho State Department of Agriculture, 2 p., accessed November 7, 2016, at http://www.agri.idaho.gov/AGRI/ Categories/Environment/water/waterPDF/factSheets/ pesticides/Payette.pdf.

Australian Bureau of Meteorology, 2016, Australian Water Information Dictionary-Hydrogeologic unit: Australian Government, Bureau of Meteorology, accessed November 7, 2016, at http://www.bom.gov.au/water/awid/id-1486.shtml.

Bahr, Gary, and Elliott, K.D., 2009, Payette and Gem Counties pesticide detections and Idaho's Pesticide Management Plan: Boise, Idaho State Department of Agriculture Fact Sheet 2-2009, 2 p., accessed November 7, 2016, at http://www.agri. idaho.gov/AGRI/Categories/Environment/water/waterPDF/ factSheets/pesticides/PayetteGem_Factsheet.pdf.

Baker, S.J., 1991, Ground-water conditions in the Dry Creek area, Eagle, Idaho: Boise, Idaho Department of Water Resources Open-File Report, 27 p., accessed November 7, 2016, at http://www.idwr.idaho.gov/files/ publications/199106-OFR-gw-conditions-drycr-eagle-id.pdf.

Baldwin, J.A., and Wicherski, Bruce, 1994, Ground water and soils reconnaissance of the lower Payette area, Payette County, Idaho: Boise, Idaho Department of Environmental Quality Ground Water Technical Report 5, 54 p., 1 app., accessed November 7, 2016, at http://www.deq.idaho.gov/ media/470592-_water_data_reports_ground_water_payette_ county_soils_recon.pdf.

Bond, J.G., Kauffman, J.D., Rember, B.C., and Shiveler, D.J., 2011, Weiser Basin evaluation: Moscow, Idaho Geological Survey Technical Report 11-1, variously paged, accessed November 7, 2016, at http://www.idahogeology.org/Products/ reverselook.asp?switch=title\&value=Weiser_Basin_ Evaluation.

Brott, C.A., Blackwell, D.D., and Mitchell, J.C., 1976, Heat flow study of the Snake River Plain region_-Part 8: Boise, Idaho Department of Water Resources Water Information Bulletin 30, 195 p., 3 pls., accessed November 7, 2016, at http://www.idwr.idaho.gov/files/publications/wib30p8geothermal-snake-river-plain.pdf.
Burnham, W.L., and Wood, S.H., 1992, Geologic map of the Boise South quadrangle, Ada County, Idaho (preprint): Preprint, in review Idaho Geological Survey technical report series, April 22, 1992, 28 p.

California Water Resources Control Board, 2016, Chemical of concern (COC) groundwater information sheet-Salinity: California Water Resources Control Board, Division of Water Quality, GAMA Program, 8 p., accessed November 7, 2016, at http://www.waterboards.ca.gov/water_issues/programs/ gama/docs/coc_salinity.pdf.

Campbell, Lin, 2006, Summary of year 2004 detections of concern, Statewide Ambient Ground Water Quality Monitoring Program: Boise, Idaho Department of Water Resources Ground Water Quality Publications, 38 p., accessed November 7, 2016, at http://www.idwr.idaho.gov/ files/publications/200604-GWQ-Detections-of-Concernyear-2004.pdf.

Carlson, Rick, and Atlakson, Jessica, 2007, Regional ground water quality monitoring results for Payette and Gem Counties, Idaho, 2003-2006: Boise, Idaho State Department of Agriculture Technical Results Summary No. 33, 7 p., accessed November 7, 2016, at http://www.agri.idaho.gov/ AGRI/Categories/Environment/water/waterPDF/gwreports/ Payette_Gem_2006.pdf.

City of Emmett and Gem County, 2014, Gem community joint comprehensive plan: City of Emmett and Gem County, Idaho, variously paged, accessed November 7, 2016, at http://www. co.gem.id.us/development-services/comprehensive-plan/ GemCompPlan.pdf.

Coplen, T.B., 1996, New guidelines for reporting stable hydrogen, carbon, and oxygen isotope-ratio data: Geochimica et Cosmochimica Acta, v. 60, no. 17, p. 3,359-3,360.

Coplen, T.B., Wildman, J.D., and Chen, Julie, 1991, Improvements in the gaseous hydrogen-water equilibration technique for hydrogen isotope ratio analysis: Analytical Chemistry, v. 63, p. 910-912.

Craig, Harmon, 1961, Isotopic variations in meteoric waters: Science, v. 133, no. 3465, p. 1,702-1,703.

Cunningham, W.L., and Schalk, C.W., comps., 2011, Groundwater technical procedures of the U.S. Geological Survey: U.S. Geological Survey Techniques and Methods book 1, chap. A1, 151 p., accessed November 7, 2016, at http://pubs.usgs.gov/tm/1a1/.

Deick, J.F., and Ralston, D.R., 1986, Ground water resources in a portion of Payette County, Idaho: Moscow, University of Idaho, Idaho Water Resources Research Institute publication number 198602, 96 p., accessed November 7, 2016, at http:// digital.lib.uidaho.edu/cdm/ref/collection/idahowater/id/397. 
Elliott, Kathryn, ed., 2015, Summary report for the Idaho Department of Environmental Quality ground water quality monitoring projects—2013: Boise, Idaho Department of Environmental Quality Ground Water Technical Report 47, 119 p., accessed November 7, 2016, at http://www.deq.idaho. gov/media/1118727/gw-monitoring-projects-summary-reporttech-report-47.pdf.

Eltschlager, K.K., Hawkins, J.W., Ehler, W.C., and Baldassare, Fred, 2001, Technical measures for the investigation and mitigation of fugitive methane hazards in areas of coal mining: Pittsburgh, Office of Surface Mining Reclamation and Enforcement, 124 p., accessed November 7, 2016, at http://www.osmre.gov/resources/library/ghm/methane.pdf.

Environmental Systems Research Institute, 2016, ArcGIS Help 10.2, 10.2.1, and 10.2.2: Environmental Systems Research Institute Web site, accessed November 7, 2016, at http:// resources.arcgis.com/en/help/main/10.2/index.html\#/Whatsne winArcGIS102/016w0000005s000000/.

Fishman, M.J., and Friedman, L.C., eds., 1989, Methods for determination of inorganic substances in water and fluvial sediments: U.S. Geological Survey Techniques of WaterResources Investigations, book 5, chap. A1, 545 p., accessed November 7, 2016, at http://pubs.water.usgs.gov/twri5a1.

Fitzgerald, J.F., 1982, Geology and basalt stratigraphy of the Weiser embayment, west-central Idaho, in Bonnichsen, Bill, and Breckenridge, R.M., eds., Cenozoic geology of Idaho: Moscow, Idaho Bureau of Mines and Geology Bulletin 26, p. 101-128, accessed November 7, 2016, at http://www.idahogeology.org/Products/reverselook. asp?switch=title\&value=Cenozoic_Geology_of_Idaho.

Forstall, Richard, ed., 1995, Idaho population of counties by decennial census-1900 to 1990: U.S. Census Bureau Web site, accessed November 7, 2016, at http://www.census.gov/ population/www/censusdata/cencounts/index.html.

Friedman, L.C., and Erdmann, D.E., 1982, Quality assurance practices for the chemical and biological analyses of water and fluvial sediments: U.S. Geological Survey Techniques of Water Resources Investigations, book 5, chap. A6, 181 p., accessed November 7, 2016, at http://pubs.er.usgs.gov/ publication/twri05A6.

Gardner, D., 2008, Community economic profile—Gem County: Bootstrap Solutions, Gem County, accessed November 7, 2016, at http://www.co.gem.id.us/pdf/BLMGem11-06-08.pdf.

Gilbert, J.D., Piety, L., and LaForge, R., 1983, Seismotectonic study, Black Canyon Diversion Dam and Reservoir, Boise Project, Idaho: Bureau of Reclamation Pacific Northwest Regional Office, Geology Branch, 137 p., 8 sheets.
Hem, J.D., 1989, Study and interpretation of the chemical characteristics of natural water, 3rd ed.: U.S. Geological Survey Water-Supply Paper 2254, 263 p., 3 pls. in pocket, accessed November 7, 2016, at http://pubs.usgs.gov/wsp/ wsp2254/.

Hooper, Peter, 2004, Ages of the Steens and Columbia River flood basalts and their relationship to extension related calcalkalic volcanism in eastern Oregon-Reply: Geological Society of America Bulletin, v. 116, no. 1-2, p. 249-250, doi: 10.1130/B25310R.1.

Idaho Department of Environmental Quality, 2008, 2008 Nitrate Priority Area delineation and ranking process: Boise, Idaho Department of Environmental Quality, 108 p., accessed November 7, 2016, at http://www.deq.idaho. gov/media/1117845/nitrate-priority-area-delineationranking-2014.pdf.

Idaho Department of Environmental Quality, 2016, Public water systems monitoring and reporting: Idaho Department of Environmental Quality Web site, accessed November 7, 2016, at http://www.deq.idaho.gov/water-quality/drinking-water/ pws-monitoring-reporting/.

Idaho Department of Labor, 2016, Workforce trend profileGem County, March 2016: Idaho Department of Labor, 2 p., accessed November 7, 2016, at http://labor.idaho.gov/ publications/lmi/pubs/GemProfile.pdf.

Idaho Department of Water Resources, 1990, Idaho streams: Boise, Idaho Department of Water Resources, GIS dataset, scale 1:100,000, accessed November 7, 2016, at https:// research.idwr.idaho.gov/index.html\#GIS-Data.

Idaho Department of Water Resources, 2016a, Well construction and drilling: Idaho Department of Water Resources database, accessed November 7, 2016, at http://www.idwr.idaho.gov/ wells/research.html.

Idaho Department of Water Resources, 2016b, Hydro.online: Idaho Department of Water Resources database, accessed November 7, 2016, at http://maps.idwr.idaho.gov/map/ hydroonline.

Idaho Department of Water Resources, 2016c, Statewide Ground Water Quality Monitoring (GWQM): Idaho Department of Water Resources Web site, accessed November 7, 2016, at https://idwr.idaho.gov/water-data/ ground-water-quality/.

Idaho Legislative Services Office, 2001, County boundaries for the State of Idaho redistricting: Boise, Idaho Legislative Services Office, GIS dataset, scale 1:100,000, accessed November 7, 2016, at http://inside.uidaho.edu/index.html.

Idaho State Climate Services, 1999, Koppen climate classification for the conterminous United States: GIS dataset, accessed November 7, 2016, at https://catalog.data.gov/ dataset/koppen-climate-classification-for-the-conterminousunited-states\#sec-dates. 
Idaho State Department of Agriculture, 2010a, Idaho State Department of Agriculture Ground Water Monitoring program-A summary of Regional Project 770, including Gem and Payette Counties (pesticide data): Idaho State Department of Agriculture, accessed November 7, 2016, at http://www.agri.idaho.gov/AGRI/Categories/Environment/ water/waterPDF/pestsummary/Project_770_Pest_2009.pdf.

Idaho State Department of Agriculture, 2010b, Idaho State Department of Agriculture Ground Water Monitoring program, a summary of Regional Project 770, including Gem and Payette Counties (inorganic data): Idaho State Department of Agriculture, accessed November 7, 2016, at http://www.agri.idaho.gov/AGRI/Categories/Environment/ water/waterPDF/inorganics/Project_770_2009.pdf.

Isotech Laboratories, Inc., 2014, Collection of ground water samples from domestic and municipal water wells for dissolved gas analysis using IsoFlasks: Isotech Laboratories, Inc., 2 p., accessed November 7, 2016, at http://www. isotechlabs.com/products/isoflask/ISOFLASK_SAMPLING. pdf.

James, A.T., 1983, Correlation of natural gas by use of carbon isotopic distribution between hydrocarbon components: American Association of Petroleum Geologists Bulletin, v. 67 , no. 7 , p. 1,176-1,191.

Johnson, Zachary, Cook, P.S., O’Laughlin, J., and Bird, K., 2013, Oil and gas resource exploration and development policies in Idaho: Moscow, University of Idaho, Policy Analysis Group Report 33, 69 p., accessed November 7, 2016, at http://www.uidaho.edu/cnr/pag/research/ publications.

Kellogg, S.T., Simon, V.A., Barlow, M., and Davidson, D.R., 1996, Ground water analysis at Emmett, Idaho: Boise, Idaho Department of Water Resources, Open-File Report, 14 p., accessed November 7, 2016, at http://www.idwr.idaho.gov/ files/publications/199605-OFR-gw-analysis-emmett-id.pdf.

Kjelstrom, L.C., 1995, Streamflow gains and losses in the Snake River and ground-water budgets for the Snake River Plain, Idaho and eastern Oregon: U.S. Geological Survey Professional Paper 1408-C, 47 p., 1 pl. in pocket, accessed November 7, 2016, at https://pubs.er.usgs.gov/publication/ pp1408C.

Lewis, R.E., and Young, H.W., 1980, Thermal springs in the Payette River Basin, west-central Idaho: U.S. Geological Survey Open-File Report 80-1020, 28 p., 2 pls. in pocket, accessed November 7, 2016, at http://pubs.er.usgs.gov/ publication/ofr801020.

Lewis, R.S., Link, P.K., Stanford, L.R., and Long, S.P., 2012, Geologic map of Idaho: Moscow, Idaho Geological Survey M-9, scale 1:750,000, 1 sheet, 18 p. booklet, accessed November 7, 2016, at http://www.idahogeology.org/Products/ reverselook.asp?switch=title\&value=Geologic_Map_of_ Idaho.
Lewis, R.S., Phillips, W.M., Feeney, D.M., Scmidt, K.L., and Wood, S.H., 2016, Geologic map of the Montour Quadrangle, Boise and Gem Counties, Idaho: Moscow, Idaho Geological Survey DWM-177, scale 1:24,000, 1 sheet, accessed November 7, 2016, at http://www.idahogeology.org/Products/ reverselook.asp?switch=title\&value=Geologic_Map_of_the_ Montour_Quadrangle,_Boise_and_Gem_Counties,_Idaho.

Lindholm, G.F., Garabedian, S.P., Newton, G.D., and Whitehead, R.L., 1983, Configuration of the water table, March 1980, in the Snake River Plain regional aquifer system, Idaho and eastern Oregon: U.S. Geological Survey Open-File Report 82-1022, 1 pl., scale 1:500,000, accessed November 7, 2016, at https://pubs.er.usgs.gov/publication/ ofr821022.

Lindholm, G.F., Garabedian, S.P., Newton, G.D., and Whitehead, R.L., 1988, Configuration of the water table and depth to water, spring 1980, water-level fluctuations, and water movement in the Snake River Plain regional aquifer system, Idaho and eastern Oregon: U.S. Geological Survey Hydrologic Investigations Atlas HA-703, 1 sheet, accessed November 7, 2016, at https://pubs.er.usgs.gov/publication/ ha703.

Lindholm, G.F., and Goodell, S.A., 1986, Irrigated acreage and other land uses on the Snake River Plain, Idaho and eastern Oregon: Geological Survey Hydrologic Investigations Atlas HA-691, 1 sheet, accessed November 7, 2016, at https://pubs. er.usgs.gov/publication/ha691.

Lutgens F.K., and Tarbuck, E.J., 1982, The Atmosphere, 2nd ed.: Englewood Cliffs, New Jersey, Prentice-Hall, 478 p.

Malde, H.E., and Powers, H.A., 1962, Upper Cenozoic stratigraphy of the western Snake River Plain, Idaho: Geological Society of America Bulletin, v. 73, p. 1,197-1,220.

Maloney, T.J., 2005, Quality Management System, U.S. Geological Survey National Water Quality Laboratory: U.S. Geological Survey Open File Report 05-1263, accessed November 7, 2016, at http://nwql.usgs.gov/rpt. shtml?OFR-05-1263.

Maupin, M.A., 1991, Depth to water in the western Snake River Plain and surrounding tributary valleys, southwestern Idaho and eastern Oregon, calculated using water levels from 1980-1988: U.S. Geological Survey Water-Resources Investigation Report 91-4020, 1 sheet, accessed November 7, 2016, at https://pubs.er.usgs.gov/publication/wri914020.

McGrath, C.L., Woods, A.J., Omernik, J.M., Bryce, S.A., Edmondson, M., Nesser, J.A., Shelden, J., Crawford, R.C., Comstock, J.A., and Plocher, M.D., 2002, Ecoregions of Idaho, level IV (2 sided color poster with map, descriptive text, summary tables, and photographs): U.S. Geological Survey, 1 sheet, scale 1:1,350,000, accessed November 7, 2016, at https://www.epa.gov/eco-research/ecoregiondownload-files-state-region-10. 
National Oceanic and Atmospheric Administration, 2016, Annual Summaries Station Details, Emmett 2 E, ID US: accessed November 7, 2016, at http://www.ncdc.noaa.gov/ cdo-web/datasets/GHCND/stations/GHCND:USC00102942/ detail.

Neeley, K.W., 2008, Trend analyses for Idaho’s nitrate priority areas, 1994-2007: Boise, Idaho Department of Water Resources, Water Information Bulletin 50, part 7, 38 p., accessed November 7, 2016, at http://www.idwr.idaho.gov/ files/publications/wib50p7-nitrate-trend-analyses.pdf.

Neeley, K.W., 2013, Trend analyses for Idaho’s Nitrate Priority Areas, 2002-2011: Boise, Idaho Department of Water Resources, Water Information Bulletin 50, Part 8, 54 p., accessed November 7, 2016, at http://www.idwr.idaho. gov/files/publications/wib50p8-Nitrate-Trend-analysesReport-2013.pdf.

Newton, G.D., 1991, Geohydrology of the regional aquifer system, western Snake River Plain, southwestern Idaho: U.S. Geological Survey Professional Paper 1408-G, 52 p., 1 pl. in pocket, accessed November 7, 2016, at https://pubs.er.usgs. gov/publication/pp1408G.

O’Connor, J.E., 1990, Hydrology, hydraulics, and sediment transport of Pleistocene Lake Bonneville flooding on the Snake River, Idaho: Tucson, University of Arizona, Ph.D. dissertation, 192 p., accessed November 7, 2016, at http://hdl. handle.net/10150/191159.

Olson, S.A., and Norris, J.M., 2005, U.S. Geological Survey Streamgaging... from the National Streamflow Information Program: U.S. Geological Survey Fact Sheet 2005-3131, 4 p., accessed November 7, 2016, at http://pubs.usgs.gov/ fs/2005/3131/.

Osborn, S.G., Vengosh, A., Warner, N.R., and Jackson, R.B., 2011, Methane contamination of drinking water accompanying gas-well drilling and hydraulic fracturing: Proceedings of the National Academy of Sciences, v. 108, no. 20, p. 8,172-8,176, doi: 10.1073/pnas.1100682108.

Othberg, K.L., 1986, Late Cenozoic geology and the Tenmile Gravel near Lucky Peak Dam, Idaho in Wood, S.H., ed., Proceedings of the 22nd symposium on engineering geology and soils engineering: Boise, Idaho, Boise State University Press, p. 533-545.

Othberg, K.L., 1994, Geology and geomorphology of the Boise Valley and adjoining areas, western Snake River Plain, Idaho: Idaho Geological Survey Bulletin 29, 54 p., accessed November 7, 2016, at http://www.idahogeology. org/Products/reverselook.asp?switch=title\&value=Geology_ and_Geomorphology_of_the_Boise_Valley_and_Adjoining_ Areas,_Western_Snake_River_Plain,_Idaho.
Othberg, K.L., and Stanford, L.R., 1992, Geologic map of the Boise Valley and adjoining area, western Snake River Plain, Idaho: Idaho Geological Survey Geologic Map GM-18, 1 sheet, scale 1:100,000, accessed November 7, 2016, at http://www.idahogeology.org/Products/reverselook. asp?switch=title\&value=Geologic_Map_of_the_Boise_ Valley_and_Adjoining_Area,_Western_Snake_River_Plain,_ Idaho.

Parliman, D.J., 1986, Quality of ground water in the Payette River basin, Idaho: U.S. Geological Survey Water-Resources Investigations Report 86-4013, 85 p., 2 pls., accessed November 7, 2016, at http://pubs.er.usgs.gov/publication/ wri864013.

Parliman, D.J., 2002, Analysis of nitrate $\left(\mathrm{NO}_{3}-\mathrm{N}\right)$ concentration trends in 25 groundwater-quality management areas, Idaho, 1961-2001: U.S. Geological Survey Water-Resources Investigations Report 02-4056, 18 p., accessed November 7, 2016, at https://pubs.er.usgs.gov/publication/wri024056.

Petrich, C.R., 2004a, Simulation of ground water flow in the lower Boise River Basin: Boise, University of Idaho, Idaho Water Resources Research Institute Research Report IWWRRI-2004-02, 130 p., accessed November 7, 2016, at http://www.idwr.idaho.gov/files/projects/treasure-valley/ TVHP-Model.pdf.

Petrich, C.R., 2004b, Treasure Valley hydrologic project executive summary: Boise, University of Idaho, Idaho Water Resources Research Institute Research Report IWWRRI-2004-04, 130 p., accessed November 7, 2016, at http://www.idwr.idaho.gov/files/projects/treasure-valley/ TVHP-Exec-Summary.pdf.

Phillips, W.M., 2007, Field trip guide to the natural hazards of the Boise Area, Idaho: Moscow, Idaho Bureau of Mines and Geology Staff Report 07-1, 26 p., accessed November 7, 2016, at http://www.idahogeology.org/Products/reverselook. asp?switch=title\&value=Field_Trip_Guide_to_the_Natural_ Hazards_of_the_Boise_Area,_Idaho.

Pritt, J.W., and Raese, J.W., 1995, Quality assurance/quality control manual-National Water Quality Laboratory: U.S. Geological Survey Open-File Report 89-409, 35 p., accessed November 7, 2016, at http://pubs.er.usgs.gov/publication/ ofr95443.

Révész, Kinga, and Coplen, T.B., 2008a, Determination of the $\delta\left({ }^{18} \mathrm{O} /{ }^{16} \mathrm{O}\right)$ of water-RSIL lab code 489 , chap. C2 of Révész, Kinga, and Coplen, T.B., eds., Methods of the Reston Stable Isotope Laboratory: U.S. Geological Survey Techniques and Methods, book 10, chap. C2, 28 p., accessed November 7, 2016, at http://pubs.usgs.gov/tm/2007/tm10c2/. 
Révész, Kinga, and Coplen, T.B., 2008b, Determination of the $\delta\left({ }^{2} \mathrm{H} /{ }^{1} \mathrm{H}\right)$ of water-RSIL lab code 1574 , chap. C1 of Révész, Kinga, and Coplen, T.B., eds., Methods of the Reston Stable Isotope Laboratory: U.S. Geological Survey Techniques and Methods, book 10, chap. C1, 27 p., accessed November 7, 2016, at http://pubs.usgs.gov/tm/2007/tm10c1/.

Roystone Hot Springs, 2016, Roystone Hot Springs-History: Roystone Hot Springs Web site, accessed November 7, 2016, at http://www.roystonehotsprings.com/about/history/.

Sadler, J.L. and Link, P.K., 1996, The Tuana Gravel—Early Pleistocene response to longitudinal drainage of a late-stage rift basin, western Snake River Plain, Idaho: Northwest Geology, v. 26, p. 46-62.

Savage, C.N., 1958, Geology and mineral resources of Ada and Canyon Counties: Moscow, Idaho Bureau of Mines and Geology County Report C-3, 111 p., 2 figures in pocket, accessed November 7, 2016, at http://www.idahogeology.org/ Products/reverselook.asp?switch=title\&value=Geology_and_ Mineral_Resources_of_Ada_and_Canyon_Counties.

Savage, C.N., 1961, Geology and mineral resources of Gem and Payette Counties: Moscow, Idaho Bureau of Mines and Geology County Report C-4, 50 p., 2 figures in pocket, accessed November 7, 2016, at http://www.idahogeology.org/ Products/reverselook.asp?switch=title\&value=Geology_and_ Mineral_Resources_of_Gem_and_Payette_Counties.

Schlegel, M.E., Mayo, A.L, Nelson, Steve, Tingey, Dave, Henderson, Rachel, and Eggett, Dennis, 2009, Paleo-climate of the Boise area, Idaho from the last glacial maximum to the present based on groundwater $\delta^{2} \mathrm{H}$ and $\delta^{18} \mathrm{O}$ compositions: Quaternary Research, v. 71, no. 2, p. 172-180.

Sharma, Shikha, Mulder, M.L., Sack, A., Schroeder, K., and Hammack, R., 2014, Isotope approach to assess hydrologic connections during Marcellus Shale drilling: Groundwater, v. 52, no. 3, p. 424-433, doi: 10.1111/gwat.12083.

SPF Water Engineering, LLC, 2004, Aquifer evaluation in the Big Gulch and Little Gulch areas of Spring Valley Ranch: Boise, Idaho, SPF Water Engineering, LLC, Report prepared for SunCor Development Company, 23 p., 6 apps., accessed November 7, 2016, at http://www.idwr.idaho.gov/Browse/ WaterInfo/NAC/consultant_reports/Avimor/Aquifer\%20 Evaluation\%2010_2004.pdf.

Squires, E., Utting, M., and Pearson, L., 2007, M3 Eagle regional hydrogeologic characterization, North Ada, Canyon, and Gem Counties, Idaho, year one progress report-May 4, 2007: Boise, Idaho, Hydro Logic, Inc., consultants’ report, 31 p., accessed November 7, 2016, at http://www. idwr.idaho.gov/Browse/WaterInfo/NAC/consultant_reports/ M3/M3\%20Eagle\%20Regional\%20Hydrogeologic\%20 Characterization\%20Year\%200ne\%20Progress\%20 Report-\%20Final\%20\%20\%20-\%20July\%2026-2007.pdf.
Squires, Edward, Wood, S.H., and Osiensky, J.L., 1992, Hydrogeologic framework of the Boise aquifer system, Ada County, Idaho: Moscow, University of Idaho, Idaho Water Resources Research Institute Research Technical Completion Report 14-08-0001-G1559-06, reprinted with corrections, $75 \mathrm{p}$.

Steed, Robert, Winter, Gerry, and Cardwell, John, 1993, Idaho Snake-Payette River hydrologic unit ground water quality assessment, west central Idaho: Boise, Idaho Department of Health and Welfare, Division of Environmental Quality, Ground Water Quality Technical Report 3, 57 p., accessed November 7, 2016, at http://deq.idaho.gov/media/470566-_ water_data_reports_ground_water_snake_payette_rivers_ hydrologic_unit_entire.pdf.

Stolper, D.A., Lawson, M., Davis, C.L., Ferreira, A.A., Santos Neto, E.V., Ellis, G.S., Lewan, M.D., Martini, A.M., Tang, Y., Schoell, M., Sessions, A.L., and Eiler, J.M., 2014, Formation temperatures of thermogenic and biogenic methane: Science, v. 344, iss. 6191, p. 1,500-1,503, doi: 10.1126/science.1254509.

Tappa, D., 2013, Isotopic composition of precipitation in a topographically complex, seasonally snow-dominated watershed-Hydrometeorological controls and variations from the global meteoric water line: Boise, Idaho, Boise State University, Master's thesis, 81 p., accessed November 7, 2016, at http://scholarworks.boisestate.edu/cgi/viewcontent. cgi ?article $=1372 \&$ context $=$ td.

U.S. Census Bureau, 2016a, QuickFacts, Gem County, Idaho: U.S. Census Bureau Web site, accessed November 7, 2016, at http://www.census.gov/quickfacts/table/PST045215/16045.

U.S. Census Bureau, 2016b, QuickFacts, Emmett City, Idaho: U.S. Census Bureau Web site, accessed November 7, 2016, at http://www.census.gov/quickfacts/table/PST045215/1625570.

U.S. Environmental Protection Agency, 2012, Drinking water contaminants, National Primary Drinking Water Regulations and National Secondary Drinking Water Regulations: U.S. Environmental Protection Agency Web site, accessed November 7, 2016, at http://water.epa.gov/drink/ contaminants/index.cfm.

U.S. Geological Survey, 2014, USGS 1:1,000,000-Scale Federal Lands of the United States 201412 Shapefile: U.S. Geological Survey Web site, accessed November 7, 2016, at https://www. sciencebase.gov/catalog/item/552d6eabe4b0b22a157f563c.

U.S. Geological Survey, 2016a, National Water Information System: Web interface, accessed November 7, 2016, at http:// dx.doi.org/10.5066/F7P55KJN.

U.S. Geological Survey, 2016b, The Branch of Quality Systems (BQS): U.S. Geological Survey Web site, accessed November 7, 2016, at https://bqs.usgs.gov. 
U.S. Geological Survey, 2016c, National Water-Quality Assessment (NAWQA) program glossary: U.S. Geological Survey Web site, accessed November 7, 2016, at http://water. usgs.gov/nawqa/glos.html.

U.S. Geological Survey, variously dated, National field manual for the collection of water-quality data: U.S. Geological Survey Techniques of Water-Resources Investigations, book 9, chaps. A1-A9, accessed November 7, 2016, at http:// pubs.water.usgs.gov/twri9A.

Western Regional Climate Center, 2016, Emmett 2 E, Idaho, Period of record monthly climate summary: Western Regional Climate Center Web site, accessed November 7, 2016, at http://www.wrcc.dri.edu/cgi-bin/cliMAIN.pl?id2942.

Whitehead, R.L., 1992, Geohydrologic framework of the Snake River Plain, Idaho and eastern Oregon: U.S. Geological Survey Hydrologic Investigations Atlas HA-681, 3 sheets, accessed November 7, 2016, at http://pubs.er.usgs.gov/ usgspubs/ha/ha681.

Whiticar, M.J., 1999, Carbon and hydrogen isotope systematics of bacterial formation and oxidation of methane: Chemical Geology, v. 161, p. 291-314.

Wicherski, Bruce, 2000, Ground water quality investigation and wellhead protection study city of Fruitland, Idaho: Boise, Idaho Department of Environmental Quality Ground Water Quality Technical Report 17, 26 p., accessed November 7, 2016, at http://deq.idaho.gov/media/470674-_water_data_ reports_ground_water_fruitland_wellhead.pdf.

Wilde, F.D., ed., 2004, Cleaning of equipment for water sampling (ver. 2.0): U.S. Geological Survey Techniques of Water-Resources Investigations, book 9, chap. A3, 79 p., accessed November 7, 2016, at http://pubs.water.usgs.gov/ twri9A3/.

Wood, S.H., 1994, Seismic expression and geological significance of a lacustrine delta in Neogene deposits of the western Snake River Plain, Idaho: American Association of Petroleum Geologists, v. 78, no. 1, p. 102-121.

Wood, S.H., 1997, Structure contour map of top of the mudstone facies, western Snake River Plain, Idaho: Boise, Idaho Department of Water Resources, Treasure Valley Hydrologic Project Report, 1 sheet, scale 1:100,000, accessed November 7, 2016, at http://www.idwr.idaho.gov/files/ projects/treasure-valley/West-Snake-mudstone-facies-map. pdf.

Wood, S.H., 2004, Geology across and under the western Snake River Plain, Idaho-Owyhee Mountains to the Boise foothills, chap. 7 in Haller, K.M., and Wood, S.H., eds., Geological field trips in southern Idaho, eastern Oregon, and northern Nevada: U.S. Geological Survey Open-File Report 2004-1222, p. 94-107, accessed November 7, 2016, at http:// pubs.usgs.gov/of/2004/1222/.
Wood, S.H., and Anderson, J.E., 1981, Geology, chap. 2 in Mitchell, J.C., ed., Geothermal investigations in Idaho-Part 11-Geological, hydrological, geochemical and geophysical investigations of the Nampa-Caldwell and adjacent area, southwestern Idaho: Boise, Idaho Department of Water Resources Water Information Bulletin No. 30, p. 9-32, accessed November 7, 2016, at http://www.idwr.idaho.gov/ files/publications/wib30p11-geothermal-nampa-caldwellareas.pdf.

Wood, S.H., Applegate, J.K., and Donaldson, P.R., 1981, Geophysics, chap. 6 in Mitchell, J.C., ed., Geothermal investigations in Idaho-Part 11-Geological, hydrological, geochemical and geophysical investigations of the NampaCaldwell and adjacent area, southwestern Idaho: Boise, Idaho Department of Water Resources Water Information Bulletin No. 30, p. 115-130, accessed November 7, 2016, at http://www.idwr.idaho.gov/files/publications/wib30p11geothermal-nampa-caldwell-areas.pdf.

Wood, S.H., and Burnham, W.L., 1983, Boise, Idaho geothermal system: Geothermal Resources Council, Transactions, v. 7, p. 215-223, accessed November 7, 2016, at http:// geology.isu.edu/Geothermal/References/GRC/Wood_and_ Burnham_1983_GRC_Trans.pdf.

Wood, S.H., and Clemens, D.M., 1982, Geologic and tectonic history of the western Snake River Plain, Idaho and Oregon, in Bonnichsen, Bill, and Breckenridge, R.M., eds., Cenozoic geology of Idaho: Moscow, Idaho Bureau of Mines and Geology Bulletin 26, p. 69-103, accessed November 7, 2016, at http://www.idahogeology.org/Products/reverselook. asp?switch=title\&value=Cenozoic_Geology_of_Idaho.

Wood, W.W., and Low, W.H., 1988, Solute geochemistry of the Snake River Plain regional aquifer system, Idaho and eastern Oregon: U.S. Geological Survey Professional Paper 1408-D, 79 p., accessed November 7, 2016, at https://pubs.er.usgs. gov/publication/pp1408D.

Young, H.W., 1985, Geochemistry and hydrology of thermal springs in the Idaho Batholith and adjacent areas, central Idaho: U.S. Geological Survey Water-Resources Investigations Report 85-4172, 44 p., 2 pls. in pocket, accessed November 7, 2016, at http://pubs.er.usgs.gov/ publication/wri854172. 


\section{Appendix A. Water-Quality Data}

Appendix A is a Microsoft ${ }^{\circledR}$ Excel file and is available for download at https://doi.org/10.3133/sir20165170. 

Publishing support provided by the U.S. Geological Survey Science Publishing Network, Tacoma Publishing Service Center

For more information concerning the research in this report, contact the Director, Idaho Water Science Center

U.S. Geological Survey

230 Collins Road

Boise, Idaho 83702

http://id.water.usgs.gov 


\section{है}

ए

言.

ڤั

종

흘.

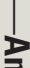

흠.

\్

웅

产

E'

를.

$\frac{0}{5}$

c్

훙

몰. 